\title{
Sources and export of particle-borne organic matter during a monsoon flood in a catchment of northern Laos
}

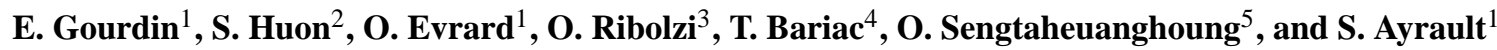 \\ ${ }^{1}$ Laboratoire des Sciences du Climat et de l'Environnement (LSCE), UMR 8212 (CEA-CNRS-UVSQ-IPSL), Domaine du \\ CNRS, avenue de la Terrasse, 91198 Gif-sur-Yvette CEDEX, France \\ ${ }^{2}$ Université Pierre et Marie Curie (UPMC), UMR 7618 iEES (UPMC-CNRS-IRD-INRA-Université Paris 7-UPEC), case 120, \\ 4 place Jussieu, 75252 Paris CEDEX 05, France \\ ${ }^{3}$ IRD, Géosciences Environnement Toulouse (GET), UMR 5563 (CNRS-UPS-IRD), 14 avenue Edouard Belin, 31400 \\ Toulouse, France \\ ${ }^{4}$ CNRS, UMR 7618 iEES (UPMC-CNRS-IRD-INRA-Université Paris 7-UPEC), campus INRA - AgroParisTech, Bâtiment \\ EGER, 78550 Thiverval-Grignon, France \\ ${ }^{5}$ Department of Agriculture Land Management (DALam), P.O. Box 4199, Ban Nogviengkham, Xaythany District, Vientiane, \\ Laos
}

Correspondence to: E. Gourdin (elian.gourdin@1sce.ipsl.fr)

Received: 26 May 2014 - Published in Biogeosciences Discuss.: 17 June 2014

Revised: 5 November 2014 - Accepted: 20 January 2015 - Published: 19 February 2015

\begin{abstract}
The yields of the tropical rivers of Southeast Asia supply large quantities of carbon to the ocean. The origin and dynamics of particulate organic matter were studied in the Houay Xon River catchment located in northern Laos during the first erosive flood of the rainy season in May 2012. This cultivated catchment is equipped with three successive gauging stations draining areas ranging between 0.2 and $11.6 \mathrm{~km}^{2}$ on the main stem of the permanent stream, and two additional stations draining 0.6 ha hillslopes. In addition, the sequential monitoring of rainwater, overland flow and suspended organic matter compositions was conducted at the $1 \mathrm{~m}^{2}$ plot scale during a storm. The composition of particulate organic matter (total organic carbon and total nitrogen concentrations, $\delta^{13} \mathrm{C}$ and $\delta^{15} \mathrm{~N}$ ) was determined for suspended sediment, soil surface (top $2 \mathrm{~cm}$ ) and soil subsurface (gullies and riverbanks) samples collected in the catchment ( $n=57,65$ and 11, respectively). Hydrograph separation of event water was achieved using water electric conductivity and $\delta^{18} \mathrm{O}$ measurements for rainfall, overland flow and river water base flow ( $n=9,30$ and 57, respectively). The composition of particulate organic matter indicates that upstream suspended sediments mainly originated from cultivated soils labelled by their $\mathrm{C}_{3}$ vegetation cover (upland rice, fallow vegetation and teak plantations). In contrast, channel banks characterized
\end{abstract}

by $\mathrm{C}_{4}$ vegetation (Napier grass) supplied significant quantities of sediment to the river during the flood rising stage at the upstream station as well as in downstream river sections. The highest runoff coefficient $(11.7 \%)$, sediment specific yield (433 $\left.\mathrm{kg} \mathrm{ha}^{-1}\right)$, total organic carbon specific yield $\left(8.3 \mathrm{~kg} \mathrm{Cha}^{-1}\right)$ and overland flow contribution (78-100\%) were found downstream of reforested areas planted with teaks. Swamps located along the main stream acted as sediment filters and controlled the composition of suspended organic matter. Total organic carbon specific yields were particularly high because they occurred during the first erosive storm of the rainy season, just after the period of slash-andburn operations in the catchment.

\section{Introduction}

Soil is a larger terrestrial reservoir of carbon than the biosphere and atmosphere combined (e.g. Sarmiento and Gruber, 2002). Although tropical soils account for ca. $30 \%$ of the total carbon storage (e.g. Dixon et al., 1994; Zech et al., 1997), high intensity storms (e.g. Goldsmith et al., 2008, Thothong et al., 2011) as well as deforestation and land use change are responsible for high soil carbon losses and deliv- 
eries to rivers. Deforestation in Laos was estimated to release ca. $85 \times 10^{12} \mathrm{gC} \mathrm{yr}^{-1}$ to the atmosphere from 1979 to 1989 (Houghton, 1991). Degens et al. (1991) identified the Asian tropical rivers (e.g. Mekong, Indus/Ganges/Brahmaputra) as the main contributors of dissolved (ca. $94 \times 10^{12} \mathrm{~g} \mathrm{C} \mathrm{yr}^{-1}$ ) and particulate (ca. $128 \times 10^{12} \mathrm{~g} \mathrm{C} \mathrm{yr}^{-1}$ ) organic matter to the oceans, by delivering more than $50 \%$ of global organic carbon inputs (about $335 \times 10^{12} \mathrm{~g} \mathrm{Cyr}^{-1}$ excluding Australia). More recently, Huang et al. (2012) estimated that the tropical rivers of Asia have the highest specific total, inorganic and organic, dissolved and particulate carbon yield in which ca. $25 \%$ of the delivery occurs as particulate organic matter (POM). This latter component does not vary linearly with total suspended sediment load (Ludwig et al., 1996), indicating that particulate organic matter is associated with higher concentrations of mineral matter in high TSS loads that are supplied to the rivers through erosion and sediment remobilization processes. Small mountainous headwater catchments play a key role in the delivery pattern because they are characterized by high specific discharges and sediment loads (Milliman and Syvitski, 1992). In this context, processes that control organic matter export from tropical catchments should be better understood and quantified, as they contribute significantly to drawdown or emission of carbon dioxide (Lal, 2003).

Tropical storms may also result in the supply of large quantities of suspended sediment to streams (Descroix et al., 2008; Evrard et al., 2010) and lead to numerous problems downstream (Syvitski et al., 2005). Sediments can accumulate behind dams, which results in the siltation of water reservoirs (Downing et al., 2008; Thothong et al., 2011). Suspended organic matter also contributes to water quality degradation (Tanik et al., 1999) and plays a major role in nutrient biogeochemical cycles (Quinton et al., 2010). It also constitutes a potential vector for various contaminants such as metals, polycyclic aromatic hydrocarbons or faecal bacteria (Ribolzi et al., 2010; Gateuille et al., 2014). In order to reduce the extent of these negative impacts, sediment delivery by rivers needs to be monitored and controlled. The design and implementation of appropriate management procedures require the identification of the processes that mobilize organic matter from soils and export suspended organic matter to rivers. To this end, total organic carbon (TOC) concentration measurements as well as natural ${ }^{15} \mathrm{~N} /{ }^{14} \mathrm{~N}$ (e.g. Mariotti et al, 1983; Kao and Liu, 2000; Huon et al., 2006) and ${ }^{13} \mathrm{C} /{ }^{12} \mathrm{C}$ (e.g. Masiello and Druffel, 2001; Hilton et al., 2010; Smith et al., 2013) stable isotope fingerprinting methods may be applied to particulate material collected from hillslopes to rivers, either independently or in combination with fallout radionuclides to document variations in sediment sources and pathways across catchments (e.g. Ritchie and McCarty, 2003; Ellis et al., 2012; Schindler Wildhaber et al., 2012; Ben Slimane et al., 2013; Koiter et al., 2013). In addition, complementary information on sediment conveyed to the river by runoff and overland flow can also be inferred from water tracers such as ${ }^{18} \mathrm{O}$ natural abundance (for a review see Klaus and McDonnell, 2013).

In this study, rainwater, stream water, overland flow and suspended sediment were sampled in the partly cultivated headwater catchment of the Houay Xon River, a small tributary of the Mekong River in Laos, during an erosive flood event that occurred at the beginning of the 2012 rainy season. The aim was to: (1) estimate the overland flow contribution to stream water and investigate its role during soil organic matter export, and (2) discriminate the respective contributions of soil and stream channel sediment in order to identify the main processes responsible for particulate organic matter delivery in nested catchments. This study builds on previous research that provided a quantification of sediment dynamics during the same flood. Gourdin et al. (2014) used fallout radionuclide measurements to quantify the contributions of soil and stream channel sources to river.

\section{Study site}

The Houay Pano catchment is located $10 \mathrm{~km}$ south of Luang Prabang in northern Laos $\left(19.84^{\circ} \mathrm{N}-102.14^{\circ} \mathrm{E}\right.$; Fig. 1). This catchment has been part of the Monitoring Soil Erosion Consortium (MSEC) network since 1998 (Valentin et al., 2008).

The tropical monsoon climate of the region is characterized by the succession of dry and wet seasons. Almost $80 \%$ of annual rainfall (1960-2013 average: $1302 \pm 364 \mathrm{~mm} \mathrm{yr}^{-1}$ ) occurs during the rainy season, from May to October (Ribolzi et al., 2008). The Houay Pano permanent stream has an average base flow of $0.4 \pm 0.1 \mathrm{~L} \mathrm{~s}^{-1}$ and is equipped with five gauging stations that subdivide the catchment into nested sub-catchments. Two of these stations, S1 and S4, draining 20 and 60 ha respectively, are located along the main stem of the stream. Two additional stations (S7 and S8) draining two hillslopes (0.6 ha each) connected to the main stream between S1 and S4 were also monitored. Between S1 and S4, water flows through a swamp $(0.19$ ha), which is fed by groundwater (Fig. 1). Only temporary foot slope and flood deposits can be found along the narrow section of the stream and the swamp represents the main sediment accumulation zone in the upper catchment. The Houay Pano stream flows into the Houay Xon River $\left(22.4 \mathrm{~km}^{2}\right.$ catchment) and then across another swamp (ca. $3 \mathrm{ha}$ ), partly occupied by fishponds (ca. $0.6 \mathrm{ha}$ ) at the outlet of the village. Stream discharge is continuously monitored at S10 (draining a $11.6 \mathrm{~km}^{2}$ sub-catchment), located $2.8 \mathrm{~km}$ downstream of S4. The Houay Xon is a tributary of the Nam Dong that flows into the Mekong River in Luang Prabang City (Ribolzi et al., 2010). Sediment connectivity between hillslopes and river is much lower in this downstream section, and most sediment therefore deposits on footslopes before reaching the river. The drainage basin that includes the highest elevations of the catchment is covered with old protected forests but no major tributary flows into the Houay 
Xon River (Fig. 1). Ephemeral left bank streams located upstream of S10 did not flow during the 23 May 2012 flood.

The geological basement of the Houay Pano upper catchment is mainly composed of pelites, sandstones and greywackes (not sampled), overlaid in its uppermost NE part by Carboniferous-Permian limestone cliffs (not sampled) that only cover a very small area in the catchment. Except for the limestone cliffs and some sections of the narrow streambed, soils or flooded soils of the swamps cover the entire catchment. They consist of deep ( $>2 \mathrm{~m}$ ) and moderately deep (>0.5 m) Alfisols (UNESCO, 1974), except along crests and ridges where Inceptisols can be found (Chaplot et al., 2009). The soils have low $\mathrm{pH}$ ranging between 4.4 and 5.5 (Chaplot et al., 2009) indicating that carbonate precipitation does not occur in soils and that they are therefore unlikely to supply particulate inorganic carbon to rivers. Native vegetation consisted of lowland forest dominated by bamboos that were first cleared to implement shifting cultivation of upland rice at the end of the 1960s (Huon et al., 2013). Elevation across the Houay Xon catchment ranges between 272 and $1300 \mathrm{~m}$ a.s.1. Steep hillslopes $\left(2-57^{\circ}\right)$ are cultivated and are therefore very sensitive to soil erosion (Chaplot et al., 2005; Ribolzi et al., 2011). Due to the decline of soil productivity triggered by soil erosion over the years (Patin et al., 2012) and to an increasing labour need to control weed invasion (Dupin et al., 2009), farmers progressively replaced rice fields with teak plantations in the catchment (Fig. 1). In 2012, the Houay Pano catchment was covered by teaks $(36 \%)$, rotating cropping lands under fallow (35\%), Job's tears $(10 \%)$, bananas (4\%), upland rice $(3 \%)$ and secondary forest $(<9 \%)$. The vegetation cover was different in the larger area drained by the Houay Xon River, with $56 \%$ forests, $15 \%$ under teak plantations and $23 \%$ croplands.

\section{Materials and methods}

\subsection{Sample and data collection}

Rainfall, stream and overland flow waters were sampled during a flood on 23 May 2012. Rainfall intensity (I) was monitored with an automatic weather station (elevation: $536 \mathrm{~m}$ a.s.1.; Fig. 1) and stream discharge was calculated from water level continuous records and rating curves. Estimates of event water discharge (EWD), defined here as the total water volume exported from each sub-catchment during the event minus the base flow discharge, were calculated by adding sequential water volumes corresponding to the average discharge between two successive water level measurements. Specific runoff (SR, in $\mathrm{mm}$ ) was obtained by dividing EWD by the corresponding sub-catchment area (Chow et al., 1988).

Rainfall was sampled with three cumulative collectors located: in the village near the confluence between the Houay Pano and Houay Xon streams, near a teak plantation on the

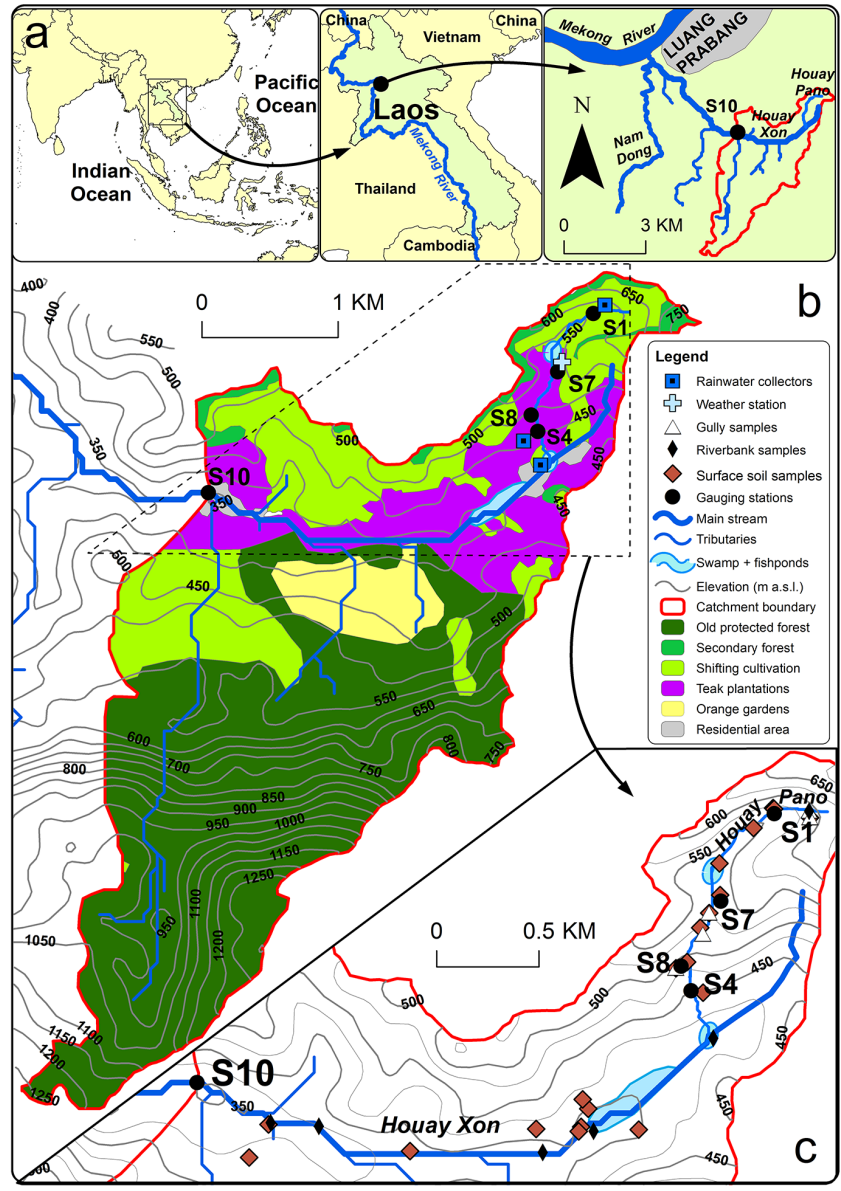

Figure 1. Location of the Houay Xon River catchment in SE Asia (a). Topographic and land use map of the Houay Xon S10 subcatchment in 2012 with location of the gauging stations (S1, S4, S7, S8, S10), rainwater collectors and automatic weather station (b), surface soil, gully and riverbank sampling locations (c).

hillslopes located just upstream of the village and within the upstream Houay Pano catchment (Fig. 1). The runoff coefficient $(\mathrm{RC})$ corresponds to the fraction of total rainfall that was exported from the catchment during the event. Overland flow was collected at the outlet of $1 \mathrm{~m}^{2}$ experimental plot $\left(\mathrm{OF}_{1 \mathrm{~m}^{2}}\right)$ during a storm on 1 June 2012 (Fig. 2; Patin et al., 2012). Rainwater was collected in a nearby ca. $8 \mathrm{~m}^{2}$ container. The experiment was conducted on a soil with $18^{\circ}$ slope and ca. $60 \%$ fallow vegetation cover $(\mathrm{ca} .10 \mathrm{~cm}$ high; Fig. 2a). The rain collector was installed at $1.8 \mathrm{~m}$ above the soil surface to avoid splash contamination. Four samples were collected in the top $3 \mathrm{~cm}$ of a soil profile $(0-5,6-10$, $11-20$, and $21-30 \mathrm{~mm}$ ) within a ca. $400 \mathrm{~cm}^{2}$ area adjacent to the experimental plot to measure the composition of organic matter in the topsoil layer (Fig. 2b).

River water was collected in $0.65 \mathrm{~L}$ polyethylene bottles for each $20 \mathrm{~mm}$ water level change by automatic samplers installed at each gauging station. Sixty-nine total suspended 

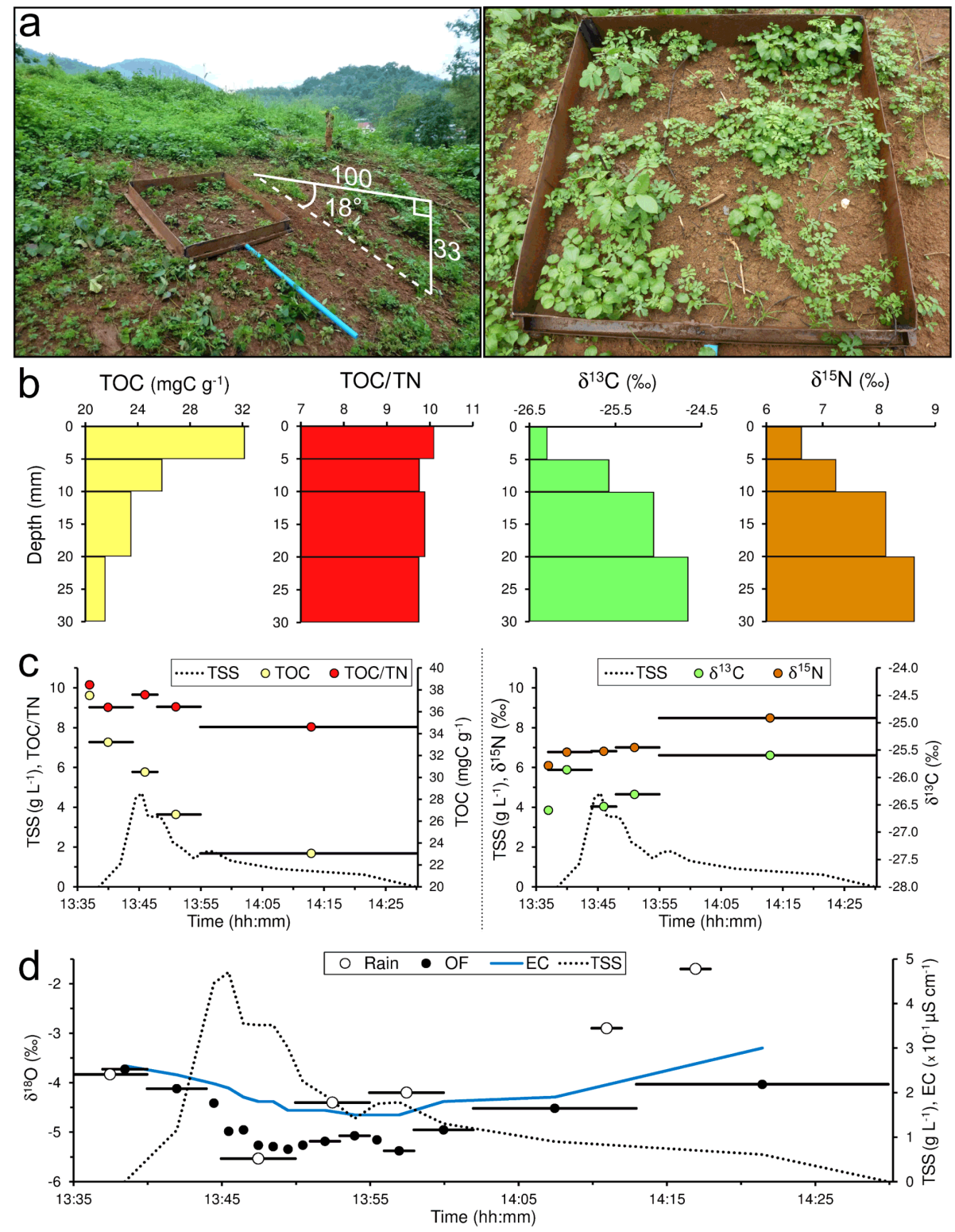

Figure 2. Microplot experiment: (a) the $1 \mathrm{~m}^{2}$ collecting system and its vegetation cover; (b) distribution of topsoil total organic carbon (TOC) concentration, total organic carbon : total nitrogen ratio (TOC / TN), $\delta^{13} \mathrm{C}$ and $\delta^{15} \mathrm{~N}$ with soil depth; (c) temporal evolution of the total suspended sediment load (TSS) plotted with TOC and TOC / TN in TSS (left) and with $\delta^{13} \mathrm{C}$ and $\delta^{15} \mathrm{~N}$ in TSS (right) during the 1 June storm and (d) temporal evolution of the overland flow TSS load with rainwater- $\delta^{18} \mathrm{O}$ (Rain), overland flow- $\delta^{18} \mathrm{O}(\mathrm{OF})$ and overland flow electric conductivity (EC) during the 1 June storm.

sediment (TSS) samples were collected at five stations, S1, S4 and S10 on the main stem and S7-S8 for hillslopes drained by ephemeral tributaries (Fig. 1). Shortly after collection, all samples were dried in $1 \mathrm{~L}$ aluminium trays in a gas oven (ca. $60-80^{\circ} \mathrm{C}$ ) for $12-48 \mathrm{~h}$. Preliminary studies carried out in 2002-2007 showed that dissolved organic carbon concentrations in the Houay Pano stream water are low, $1.8 \pm 0.4 \mathrm{mg} \mathrm{L}^{-1}(n=74)$ and $2.0 \pm 0.7 \mathrm{mg} \mathrm{L}^{-1} \quad(n=65)$, during base flow and peak discharge, respectively. With highsuspended sediment loads (see Sect. 4 for more detail), a
$3 \mathrm{mg} \mathrm{C} \mathrm{L}{ }^{-1}$ content for dissolved organic matter would represent $1-10 \mathrm{wt} \%$ of the total (dissolved and particulate) organic carbon load. On average, $97 \pm 3 \%$ of the total organic matter recovered during the flood was particulate. Our results are therefore very likely to reflect the composition and behaviour of particle-bound organic matter, as the dissolved fraction was negligible. To expand the topsoil data set available for the catchment (Huon et al., 2013), additional soil cores were collected on hillslopes connected to the Houay Pano stream and the Houay Xon River (Fig. 1) in May and 
Table 1. Estimates of event water discharge (EWD) and related specific runoff (SR) and runoff coefficient (RC) for the three stations during the 23 May 2012 flood.

\begin{tabular}{lrrrr}
\hline Station & $\begin{array}{r}\text { Drainage } \\
\text { area }\left(\mathrm{km}^{2}\right)\end{array}$ & $\begin{array}{r}\mathrm{EWD}^{*} \\
\left(\times 10^{6} \mathrm{~L}\right)\end{array}$ & $\begin{array}{r}\mathrm{SR}^{* *} \\
(\mathrm{~mm})\end{array}$ & $\begin{array}{r}\mathrm{RC}^{* * *} \\
(\%)\end{array}$ \\
\hline S1 & 0.2 & 0.215 & 1.1 & 4.0 \\
S4 & 0.6 & 1.88 & 3.2 & 11.7 \\
S10 & 11.6 & 12.2 & 1.1 & 3.9 \\
\hline
\end{tabular}

* $\mathrm{EWD}=$ total water discharge minus baseflow discharge;

** $\mathrm{SR}=\mathrm{EWD} /$ drainage area;

$* * * \mathrm{RC}=100 \times(\mathrm{SR} /$ rainfall $)$ assuming an homogeneous cumulative rainfall of $27 \mathrm{~mm}$.

December 2012. Several gully $(n=5)$ and riverbank $(n=6)$ samples were also collected in December 2012 to document the characteristics of the potential subsurface sources of sediment to the river.

Cumulated suspended sediment yields (SSY) were calculated at each station by summing the total suspended sediment (TSS) exports between successive samples. The TSS concentration was considered to vary linearly between successive measurements. Specific sediment yields $\left(S_{\mathrm{Y}}\right)$ were calculated by dividing the cumulated SSY by the corresponding drainage area.

\subsection{Particulate organic matter composition measurements}

All samples were finely ground with an agate mortar, weighed and packed into tin capsules $(5 \times 9 \mathrm{~mm})$ for analysis. Total organic carbon (TOC) and total nitrogen (TN) concentrations, and ${ }^{13} \mathrm{C} /{ }^{12} \mathrm{C}$ and ${ }^{15} \mathrm{~N} /{ }^{14} \mathrm{~N}$ stable isotopes were measured using the Elementar ${ }^{\circledR}$ VarioPyro cube analyzer on line with a Micromass ${ }^{\circledR}$ Isoprime Isotope Ratio Mass Spectrometer (IRMS) facility (iEES, Paris). Analytical precision was better than $\pm 0.2-0.3 \%$ ovs. PDB-AIR standards (Coplen et al., 1983) and $0.1 \mathrm{mg} \mathrm{g}^{-1}$ (equivalent to $0.01 \mathrm{wt} \%$ ) for $\delta^{13} \mathrm{C}-\delta^{15} \mathrm{~N}$ and TOC-TN, respectively. Data reproducibility was checked by conducting replicate analyses of a $99 \%$ pure tyrosine laboratory standard (Girardin and Mariotti, 1991) using 18 tyrosines per batch of 50 samples. Analysis of a selection of samples was repeated and did not show any variation in the measurements. The presence of carbonate minerals and carbonate rock fragments in the samples was excluded after performing a test using a $30 \% \mathrm{HCl}$ solution (no $\mathrm{CO}_{2}$ bubbling). For the entire flood, total particulate organic carbon yields $\left(\mathrm{C}_{\mathrm{SSY}}\right)$ were calculated by summing the successive TOC contents associated with suspended sediments (SSY multiplied by TOC concentration). The TOC concentration of particulate organic matter was assumed to vary linearly between successive samples. Specific TOC yields $\left(\mathrm{C}_{\mathrm{Y}}\right)$ were calculated by dividing the cumulated $\mathrm{C}_{\mathrm{SSY}}$ by the corresponding drainage area.

\subsection{Water $\delta^{18} \mathrm{O}$ and electrical conductivity measurements}

Water aliquots were recovered in $30 \mathrm{~mL}$ glass flasks from stream, overland flow and rain samples (see Sect. 3.1 for details) and filtered using $<0.2 \mu \mathrm{m}$ acetate filters. Stable ${ }^{18} \mathrm{O} /{ }^{16} \mathrm{O}$ isotope measurements were carried out using the standard $\mathrm{CO}_{2}$ equilibration method (Epstein and Mayeda, 1953) and determined with a VG Optima ${ }^{\circledR}$ mass spectrometer (iEES, Thiverval-Grignon). Isotopic ratios are reported using the $\delta^{18} \mathrm{O}$ notation, relative to the Vienna-Standard Mean Ocean Water (V-SMOW; Gonfiantini, 1978) with an analytical precision better than $\pm 0.1 \%$. Water electrical conductivity (EC) was measured every $6 \mathrm{~min}$ at the inlet of each gauging station using Schlumberger in situ CTD probes. Additional measurements were conducted using an $\mathrm{YSI}^{\circledR}$ 556 probe for manually collected samples. Hydrograph separation was obtained by applying end-member mixing equations using water electrical conductivity and $\delta^{18} \mathrm{O}$ measurements (Sklash and Farvolden, 1979; Ribolzi et al., 2000; Ladouche et al., 2001).

\section{Results}

\subsection{Composition of the potential sources of particulate organic matter in the catchment}

The mean organic matter characteristics are reported in Table 1 for surface soils, gullies and stream banks collected in the catchment, together with ${ }^{137} \mathrm{Cs}$ activities determined on the same sample aliquots (Huon et al., 2013; Gourdin et al., 2014). High ${ }^{137} \mathrm{Cs}$ activities are measured in surface soil samples, whereas gully and riverbank sites are depleted in this radioisotope (Table 1).

Surface (soils) and subsurface (channel banks and gullies) sources of particulate organic matter are best discriminated by their TOC content, which is significantly higher in surface soils. The dominance of $\mathrm{C}_{3}$ photosynthetic pathway plants across the catchment is reflected by low $\delta^{13} \mathrm{C}$ values in soils $(-25.5 \pm 1.4 \%$ o). However, soil-originating particles accumulated in sediments of the swamp provide ${ }^{13} \mathrm{C}$-enriched compositions, up to ca. $-15 \%$, that are explained by the input of organic matter derived from $\mathrm{C}_{4}$ photosynthetic pathway plant tissues. The $\mathrm{C}_{4}$ plants found in the catchment are mainly Napier grasses growing in the swamp and along some sections of the stream channel, and to a much lower extent, Job's tears and maize cultivated on nearby hillslopes (Huon et al., 2013). Soil surface and subsurface sources can also be distinguished by their $\delta^{15} \mathrm{~N}$ values, which are slightly lower for the former (Table 1). The results reflect high ${ }^{15} \mathrm{~N} /{ }^{14} \mathrm{~N}$ fractionation during incorporation and mineralization of plant tissues in soils, which is typical in tropical environments (e.g. Amundson et al., 2003). 
Table 2. Mean organic matter composition and ${ }^{137}$ Cs activity ( \pm 1 standard deviation) for surface soils $(n=64)$, gullies $(n=5)$ and stream bank $(n=6)$ samples in the Houay Pano and Houay Xon catchments. For ${ }^{137}$ Cs activity measurements, see Gourdin et al. (2014).

\begin{tabular}{lllllll}
\hline Location & $\begin{array}{l}\text { TOC } \\
\left(\mathrm{mg} \mathrm{Cg}^{-1}\right)\end{array}$ & $\begin{array}{l}\mathrm{TN} \\
\left(\mathrm{mg} \mathrm{Ng}^{-1}\right)\end{array}$ & $\begin{array}{l}\mathrm{TOC} / \mathrm{TN} \\
\delta^{13} \mathrm{C} \\
(\% o)\end{array}$ & $\begin{array}{l}\delta^{15} \mathrm{~N} \\
(\% o)\end{array}$ & $\begin{array}{l}{ }^{137} \mathrm{Cs} \\
\left(\mathrm{Bq} \mathrm{kg}^{-1}\right)\end{array}$ \\
\hline Surface soils* & $25 \pm 5$ & $2.1 \pm 0.5$ & $11.6 \pm 2.0$ & $-25.5 \pm 1.4$ & $6.7 \pm 1.3$ & $2.2 \pm 0.9$ \\
Stream banks** & $13 \pm 6$ & $1.1 \pm 0.3$ & $12.4 \pm 7.7$ & $-23.2 \pm 4.4$ & $8.6 \pm 1.9$ & $0.4 \pm 0.3$ \\
Gullies** & $14 \pm 7$ & $1.4 \pm 0.6$ & $9.6 \pm 0.8$ & $-22.7 \pm 0.8$ & $8.7 \pm 2.1$ & $0.4 \pm 0.3$ \\
\hline
\end{tabular}

${ }^{*}$ Data from Huon et al. (2013) and this study (2012), ** this study (2012).

\subsection{Monitoring water and particulate organic matter export at the microplot scale during a rainfall event}

The distribution of organic matter composition with soil depth is displayed in Fig. 2 b. The TOC content decreases exponentially with depth together with TN (not plotted), leading to a nearly constant TOC : TN ratio of ca. 10 (Fig. 2b). Both $\delta^{13} \mathrm{C}$ and $\delta^{15} \mathrm{~N}$ increase with soil depth from -26.3 to $-24.7 \%$ and from 6.6 to $8.6 \%$, respectively, reflecting the contribution of fallow vegetation debris depleted in ${ }^{13} \mathrm{C}$ and ${ }^{15} \mathrm{~N}$ with respect to soil organic matter (Balesdent et al., 1993). Overland flow samples (OF) were collected continuously at the outlet of the experimental plot during the 1 June storm that lasted for $45 \mathrm{~min}$. Cumulated rainfall was ca. $11 \mathrm{~mm}$ and its intensity reached $30 \mathrm{~mm} \mathrm{~h}^{-1}$ during $20 \mathrm{~min}$. Suspended sediment concentration increased to a maximum of $4.7 \mathrm{~g} \mathrm{~L}^{-1}$ (Fig. 2c-d). The estimated runoff coefficient was $77 \%$ during the entire storm with an average infiltration rate of $3.3 \mathrm{~mm} \mathrm{~h}^{-1}$, assuming no evaporation during rainfall. As shown in Fig. 2c, suspended sediments exported from the experimental plot were characterized by TOC, TOC / TN, $\delta^{13} \mathrm{C}$ and $\delta^{15} \mathrm{~N}$ values that match topsoil organic matter composition (Fig. 2b), with a slight evolution towards the composition of deeper superficial layers $(1-3 \mathrm{~cm})$ at the end of the event. The higher TOC and lower $\delta^{13} \mathrm{C}$ and $\delta^{15} \mathrm{~N}$ values recorded at the beginning of the storm likely result from the preferential export of fine soil organic matter. Similar behaviours were reported by Clark et al. (2013) in the tropical Andes. They were associated with a greater contribution of non-fossil particulate organic carbon (POC) during the rising stage and the peak discharge. In contrast, in the Swiss Alps, the initial decrease of POC during the rising stage was assumed to result from in-channel clearing (Smith et al., 2013). The evolution of rainwater and $\mathrm{OF}-\delta^{18} \mathrm{O}$ is shown in Fig. 2d. At the beginning of the storm, both parameters displayed a similar decreasing $\delta^{18} \mathrm{O}$ trend (from -3.8 to $-5.5 \%$ ) with increasing rainfall intensity, concomitant to a rise of the suspended load. Overland flow EC averaged $20 \pm 6 \mu \mathrm{S} \mathrm{cm}^{-1}$ (range: $15-36 \mu \mathrm{S} \mathrm{cm}^{-1}, n=17$ ). The values are consistent with those of two other cumulated OF samples ( 21 and $43 \mu \mathrm{S} \mathrm{cm}^{-1}$ ) collected in the Houay Pano catchment during the 23 May 2012 event (see Sect. 4.3). Contrasting increasing trends were also observed for rain- and $\mathrm{OF}_{-}{ }^{18} \mathrm{O}$ contents (reaching -1.7 and $-4.0 \%$, respectively) during the falling water stage. They reflected the mixing of progressively ${ }^{18} \mathrm{O}$-enriched rainwater with former ${ }^{18} \mathrm{O}$-depleted rainwater temporarily stored in the topsoil. It is likely that the OF that triggers soil erosion and suspended sediment export better reflects the contribution of event water to the stream than rainfall.

\subsection{Hydro-sedimentary characteristics of the 23 May 2012 flood}

This flood was triggered by a $48 \mathrm{~min}$ storm that brought $27 \mathrm{~mm}$ of cumulated rainfall between 11:36a.m. and 12:24 p.m. According to Bricquet et al. (2003), this event has a return period of ca. $0.01 \mathrm{yr}\left(34.7 \mathrm{~mm} \mathrm{day}^{-1}\right)$. It was the first significant erosive event of the 2012 rainy season and the first event with rainfall intensity exceeding $80 \mathrm{~mm} \mathrm{~h}^{-1}$ (6 min time steps). The main hydro-sedimentary characteristics of the flood are reported for the three gauging stations in Fig. 3I/II/IIIa-d.

The lag time between stream discharge $(Q)$ and rainfall intensity peaks differed at the three stations. $Q$ increased $10 \mathrm{~min}$ after the rainfall peak and reached its maximum $10 \mathrm{~min}$ later at S1 (Fig. 3Ia), whereas both peaks were synchronous at S4 (Fig. 3IIa). Downstream, the lag time between rainfall and $Q$ peaks increased to $70 \mathrm{~min}$ at $\mathrm{S} 10$ (Fig. 3IIIa). The evolution of TSS concentration that peaked at 24$47 \mathrm{~g} \mathrm{~L}^{-1}$ (Fig. 3I/II/IIIb) displayed counterclockwise hysteresis dynamics (Williams, 1989; Lenzi and Marchi, 2000) at the three stations. Even though $Q$ increased faster than TSS concentration at the beginning of the flood, water EC decreased concomitantly at the three stations (Fig. 3I/II/IIIc). This behaviour suggests the progressive mixing of pre-event water (i.e. groundwater) with a low TSS load by weakly mineralized event water (i.e. overland flow) with high sediment loads, the proportion of the latter increasing with decreasing EC. Pre-event EC values measured in the stream just before the flood were 394,320 and $450 \mu \mathrm{S} \mathrm{cm}^{-1}$ at S1, S4 and S10, respectively (Fig. 3I/II/IIIc) and strongly differed from the low values determined for OF (see above). As expected, the highest values were recorded at S10, which is located downstream of riparian villages (Ribolzi et al., 2010) where wastewaters characterized by high EC are directly released 
into the river. In contrast, upstream of this village, stream waters exclusively originate from cultivated lands. Pre-event water ${ }^{18} \mathrm{O}$ content was estimated to be $-7.1 \%$ at station S4 with samples collected before peak flow rise (Fig. 3IId). However, for S1 and S10, automatic sampling only took place during the water rising stage and the composition of pre-event water had to be estimated. At $\mathrm{S} 1$, a $\delta^{18} \mathrm{O}$ value of $-8 \%$ o corresponding to a maximum EC of $394 \mu \mathrm{Sm}^{-1}$ was estimated by fitting the correlative trend (see Sect. 5). Pre-event and event waters could not be distinguished with $\delta^{18} \mathrm{O}$ signatures at $\mathrm{S} 10$. Overall, despite the limited number of samples collected, the composition of cumulated rainwater remained rather constant in the catchment $(-5.1,-5.5$ and $-5.6 \%$ ), with an average of $-5.4 \pm 0.3 \%$.

\subsection{Particulate organic matter export at catchment scales during the 23 May 2012 flood}

Large variations in suspended organic matter composition were recorded at $\mathrm{S} 1$ with TOC concentration $(20-70 \mathrm{mg}$ $\mathrm{Cg}^{-1}$, Fig. 3Ie), TOC / TN (8-31, Fig. 3If), $\delta^{13} \mathrm{C}$ ( -26 to $-15 \%$, Fig. 3Ig) and $\delta^{15} \mathrm{~N}(5.5-8.0 \%$, Fig. 3Ih) measurements. They all indicate changes in the source delivering suspended organic matter to the river during the rising water stage. The $\delta^{13} \mathrm{C}$ signature of suspended organic matter reaches the average composition $(-25.5 \pm 1.4 \%$; Table 1$)$ of topsoil organic matter in the catchment at peak flow and during the recession stage (Fig. 3I/IIg). Due to larger and more heterogeneous areas drained at S4 and S10, the temporal evolution of TOC / TN, $\delta^{13} \mathrm{C}$ and $\delta^{15} \mathrm{~N}$ in TSS (Fig. 3II/IIIe-h) was less contrasting than at S1. At S10, the mean TOC / TN was higher $(17.0 \pm 3.2)$ than at $S 1(13.1 \pm 5.9)$ and $S 4$ $(10.3 \pm 0.9)$, reflecting a greater contribution of vegetation debris and/or weakly mineralized organic matter downstream than in upper parts of the catchment (Table A1 in Appendix A). Furthermore, the highest TOC / TN (23; Fig. 3IIIf) was obtained during the water peak discharge at S10 whereas it was recorded at the beginning of the rising stage at S1 (31; Fig. 3If).

\section{Interpretation and discussion}

\subsection{Overland flow contribution to stream discharge}

\subsubsection{Evolution of water composition during the flood}

Water electrical conductivity and $\delta^{18} \mathrm{O}$ measurements conducted on rainwater, overland flow and stream water highlight in-channel mixing processes between base flow groundwater (pre-event water) and event water characterized by contrasting signatures (Fig. 4I).

At S1 (Fig. 4Ia), all samples are aligned between the $\mathrm{PEW}$ and $\mathrm{OF}_{1 \mathrm{~m}^{2}}$ end-members during both rising and recessing stages, suggesting that the composition of corresponding sources remained constant during the event. This condition

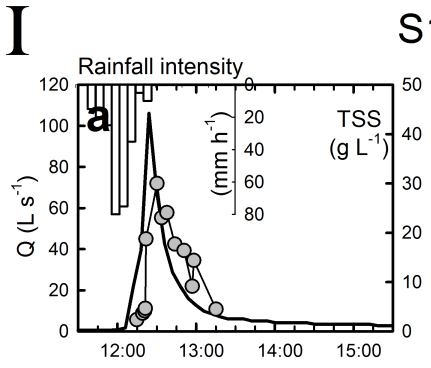

S1
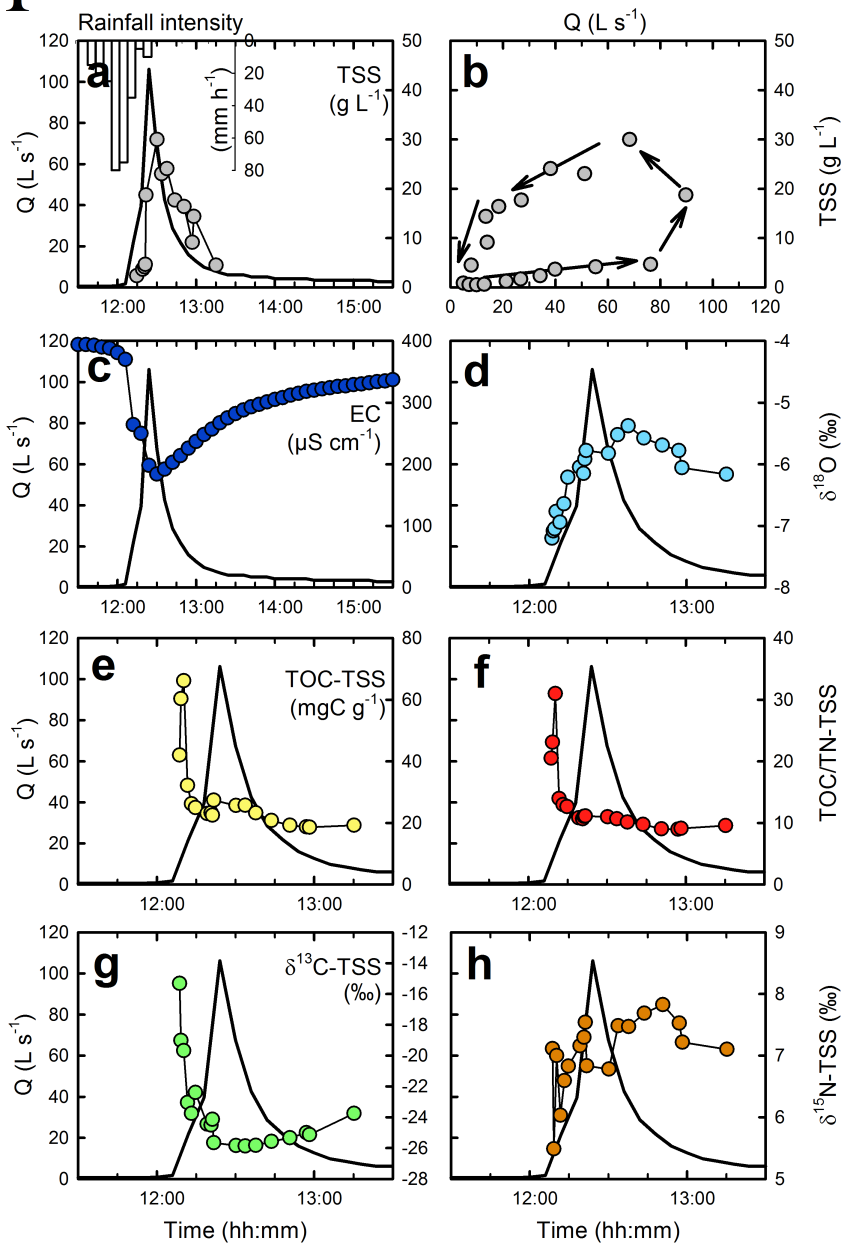

Figure 3. Plots of the temporal evolution of (a) rainfall intensity, stream discharge ( $Q$, thicker solid line), (b) total suspended sediment load (TSS), (c) water electric conductivity (EC), (d) stream water- $\delta^{18} \mathrm{O}$, (e) total organic carbon concentration in the TSS (TOC-TSS), (f) total organic carbon : total nitrogen ratio in the TSS (TOC / TN-TSS), (g) $\delta^{13} \mathrm{C}-\mathrm{TSS}$, (h) $\delta{ }^{15} \mathrm{~N}$-TSS for: (I) the upstream station $\mathrm{S} 1$, (II) the intermediate station $\mathrm{S} 4$, and (III) the downstream station S10, during the 23 May 2012 flood. Horizontal bars represent sampling period for composite samples.

is one of the assumptions underpinning hydrograph separation procedures (e.g. Buttle, 1994; Ribolzi et al., 2000; Klaus and McDonnell, 2013). At S4 (Fig. 4Ib), the evolution of stream water composition during the flood displays a more complex pattern, with the succession of three phases characterized by distinct behaviours. During the rising stage, the trend between PEW and $\mathrm{OF}_{1 \mathrm{~m}^{2}}$ is similar to the situation observed at S1. Near peak flow, stream water EC and $\delta^{18} \mathrm{O}$ concomitantly decrease towards the signature of cumulated rainwater samples (Fig. 4Ib) until the dilution of PEW by EW reaches its maximum. This behaviour likely reflects the progressive depletion of rainwater in ${ }^{18} \mathrm{O}$ during the storm, as 
II

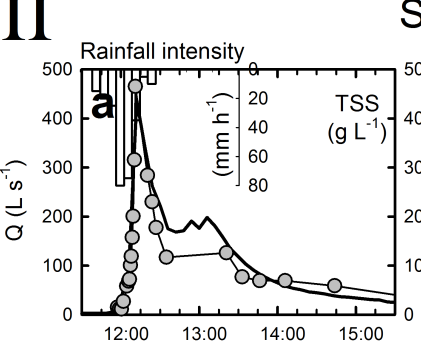

S4
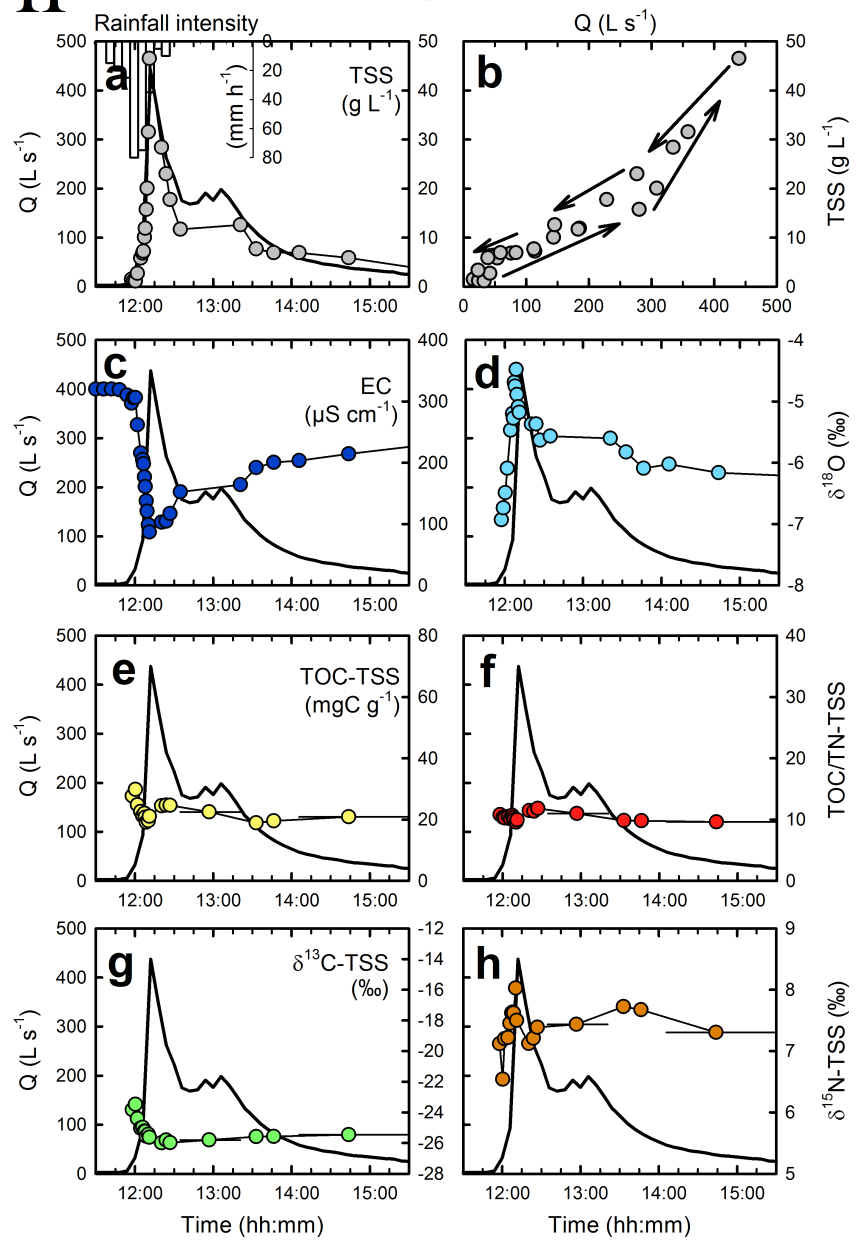

Figure 3. Continued.

observed during the microplot experiment (Fig. 2d), following a Rayleigh-type distillation process (Dansgaard, 1964). The decrease of EC in stream water is also consistent with the supply of weakly mineralized overland flow water mixing rainwater and pre-event soil water with low and high dissolved loads, respectively. A remarkable point is that the water composition supplied by S7-S8 sub-catchments, referred to as $\mathrm{OF}_{0.6 \text { ha }}$ (Fig. 4Ib), closely matches the composition of stream water during this period. Finally, during the third phase corresponding to the recession period, the composition of the river water evolved towards the "initial" PEW signature along a third mixing line. At S10, stream water composition displayed large variations in EC but limited changes in $\delta^{18} \mathrm{O}$ (range: from -6.0 to $-5.2 \%$; Fig. $4 \mathrm{Ic}$ ). The EC values, decreasing from 450 to $155 \mu \mathrm{S} \mathrm{cm}^{-1}$ at the beginning of the event (Fig. 3IIIc), suggest a high contribution of OF at this station.

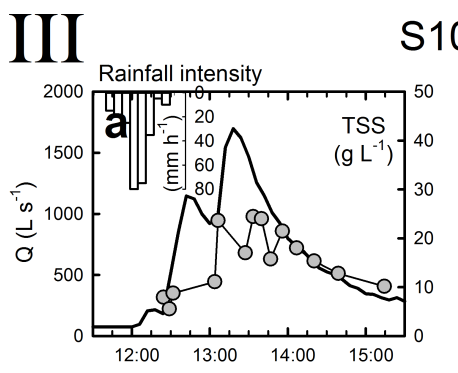

S10
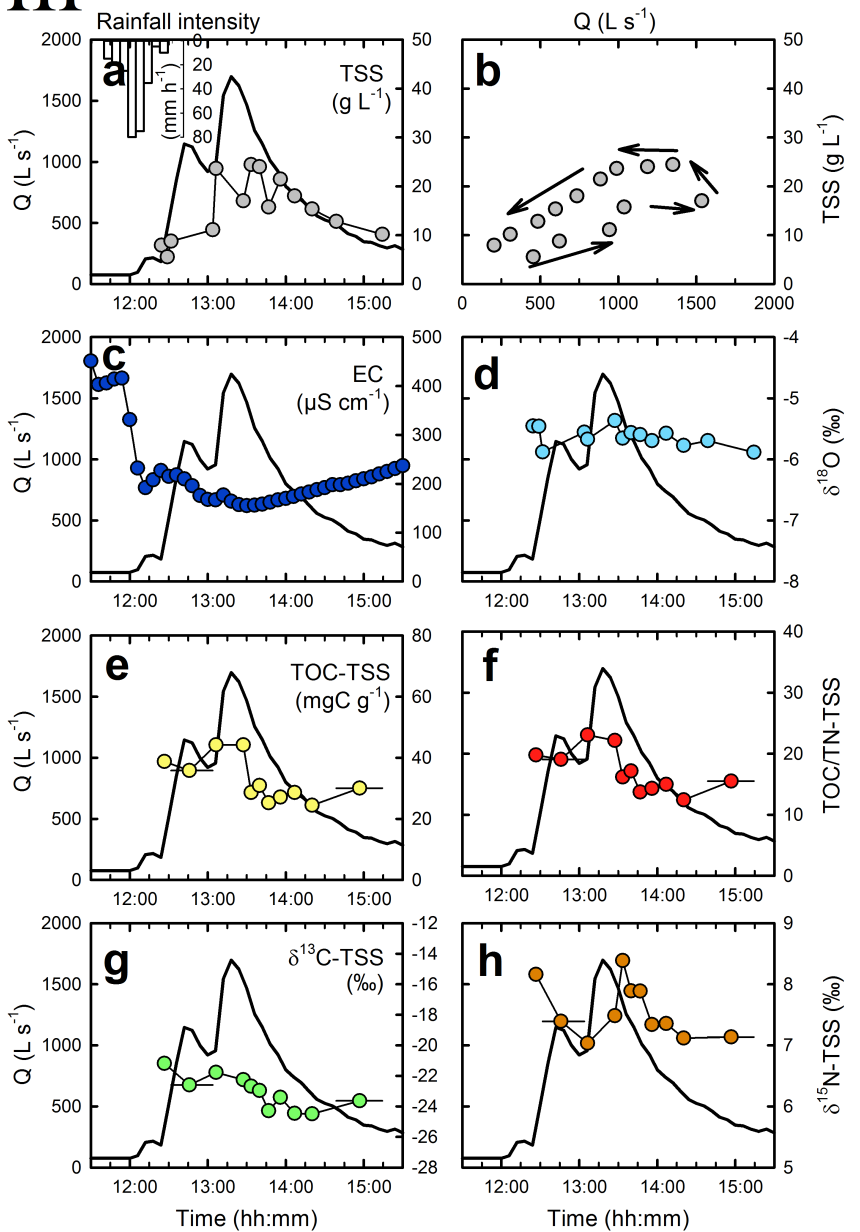

Figure 3. Continued.

\subsubsection{Catchment hydrological characteristics inferred from hydrograph separation}

As highlighted by Klaus and McDonnell (2013), highfrequency analyses of rainfall and runoff are necessary to record end-members intra-event signature variations and reduce uncertainties associated with hydrograph separation. The microplot experiment recorded these temporal variations during a single storm event (Fig. 2d). The OF signature displayed lower variations $(-5.5$ to $-3.7 \%$ o $)$ than rainwater $(-5.6$ to $-1.7 \%$ ) as a result of mixing between rain and soil water. Although samples could not be taken during the 23 May 2012 flood, a similar intra-storm evolution magnitude of ca. $2 \%$ for $\mathrm{OF}-\delta^{18} \mathrm{O}$ was assumed. In order to estimate event water contribution to total water discharge monitored at each station, this possible intra-storm variation of rainwater and overland flow signature must be taken into account (McDonnell et al., 1990). The very close $\delta^{18} \mathrm{O}$ values obtained for the three rainwater samples collected on 23 May 2012 across the catchment remain consistent with the 

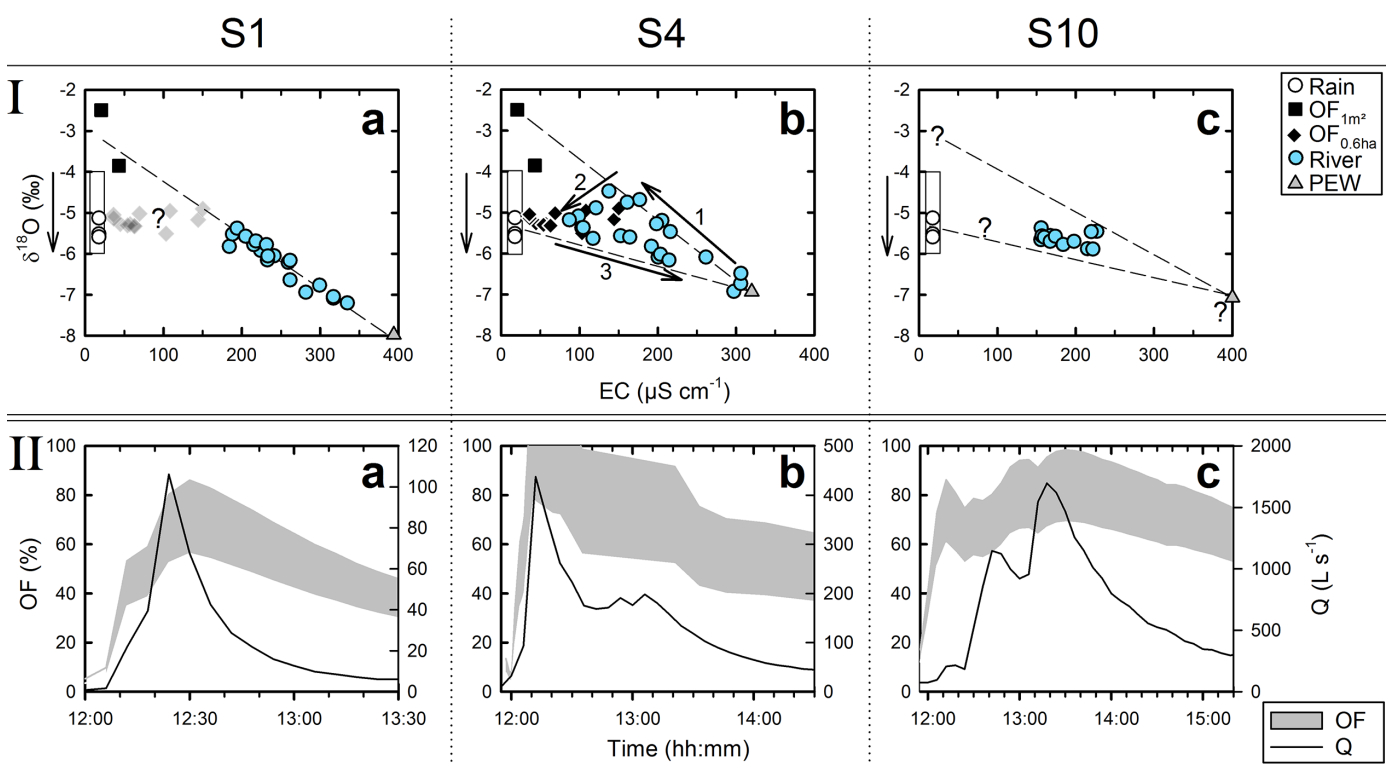

Figure 4. Plots of: (I) relationships between water electric conductivity (EC) and water $\delta^{18} \mathrm{O}$, and (II) temporal evolution of stream water discharge $(Q)$ with overland flow contribution estimates (OF) for (a) the upstream station $\mathrm{S} 1$, (b) the intermediate station $\mathrm{S} 4$, and (c) the downstream station S10, during the 23 May 2012 flood. In (I), open circles correspond to rainwater, filled squares to cumulative overland flow obtained with $1 \mathrm{~m}^{2}$ plots $\left(\mathrm{OF}_{1 \mathrm{~m}^{2}}\right)$, filled diamonds to overland flow from $\mathrm{S} 7$ and $\mathrm{S} 8$ hillslopes $\left(\mathrm{OF}_{0.6 \mathrm{ha}}\right)$, filled coloured circles to stream water, and triangles to pre-event water (PEW). The rectangle areas and vertical arrows represent the potential temporal variability of rainwater- $\delta^{18} \mathrm{O}$ during the storm. In (II), the shaded area corresponds to the variability range for the estimated overland flow contribution.

first assumption formulated by Harris et al. (1995) regarding the spatial uniformity of cumulated rainwater isotopic signature. However, the behaviour of stream water during peak discharge at S4 (Figs. 3IId, 4Ib) suggests the evolution of the $\mathrm{OF}$ end-member signature towards low $\delta^{18} \mathrm{O}$ (as recorded for $\mathrm{OF}_{0.6 \mathrm{ha}}$ in Fig. $4 \mathrm{Ib}$ ), consistent with a Rayleigh-type distillation of rainwater. Pre-event soil water signature, likely enriched in ${ }^{18} \mathrm{O}$ by evaporation at the onset of the rainy season (e.g. Hsieh et al., 1998), could not be characterized. Its higher $\delta^{18} \mathrm{O}$ range can be assumed to be responsible for the higher $\delta^{18} \mathrm{O}$ observed for $\mathrm{OF}_{1 \mathrm{~m}^{2}}$ during the 23 May 2012 flood $(-3.9$ to $-2.5 \%$; Fig. 4Ib). The higher EC values recorded for $\mathrm{OF}_{0.6 \mathrm{ha}}$ compared to $\mathrm{OF}_{1 \mathrm{~m}^{2}}$ likely result from the supply of dissolved elements by runoff because of interactions between rainwater, vegetation, and soil particles along hillslopes. As the temporal evolution of rainwater and of the resulting OF- $\delta^{18} \mathrm{O}$ values could not be measured during the 23 May 2012 flood, we used EC only to provide estimates of overland flow contribution, taking into account the potential variation of this end-member signature, from 20 to $150 \mu \mathrm{S} \mathrm{cm}^{-1}$, during the event (Fig. 4II).

Estimates of event water discharge (EWD), specific runoff (SR) and runoff coefficient (RC) are summarized in Table 2. Runoff coefficients are rather low in most parts of the catchment (4.0 and $3.9 \%$ at S1 and S10, respectively), except at S4 where a higher value of $11.7 \%$ was obtained (Table 2). Overall, those low runoff coefficients remained consistent with the high infiltration rates reported by Patin et al. (2012) in soils of the same area $\left(>100 \mathrm{~mm} \mathrm{~h}^{-1}\right)$. Chaplot and Poesen (2012) reported an annual runoff coefficient of ca. $13 \%$ for twelve $1 \mathrm{~m}^{2}$ plots monitored in this catchment. The values decrease in the downstream direction, down to $6 \%$ for $\mathrm{S} 4$ and $1.5 \%$ for S10. Estimates of the OF contribution to total water discharge, based on the evolution of water EC, are displayed on Fig. 4II. At peak discharge, OF was lower at S1 (53-80\%) than at S4 (78-100\%) and S10 (67-95\%). The highest value was obtained at S4 where the highest runoff coefficient was also recorded. This behaviour likely results from a different soil cover in this sub-catchment where $32 \%$ of the surface is covered with teak, compared to 14 and $15 \%$ upstream of S1 and $\mathrm{S} 10$, respectively. These teak plantations are prone to soil erosion and characterized by low infiltration rates (Patin et al., 2012). Moreover, the annual runoff coefficients reported by Chaplot and Poesen (2012) at S4 and S10 were lower than those calculated in this study, but they were measured when teak plantations covered a much smaller surface area in the catchment (2002-2003, Chaplot et al., 2005). Overall, it is likely that teak plantations will enhance overland flow and soil erosion at least during the years following their land use conversion. 


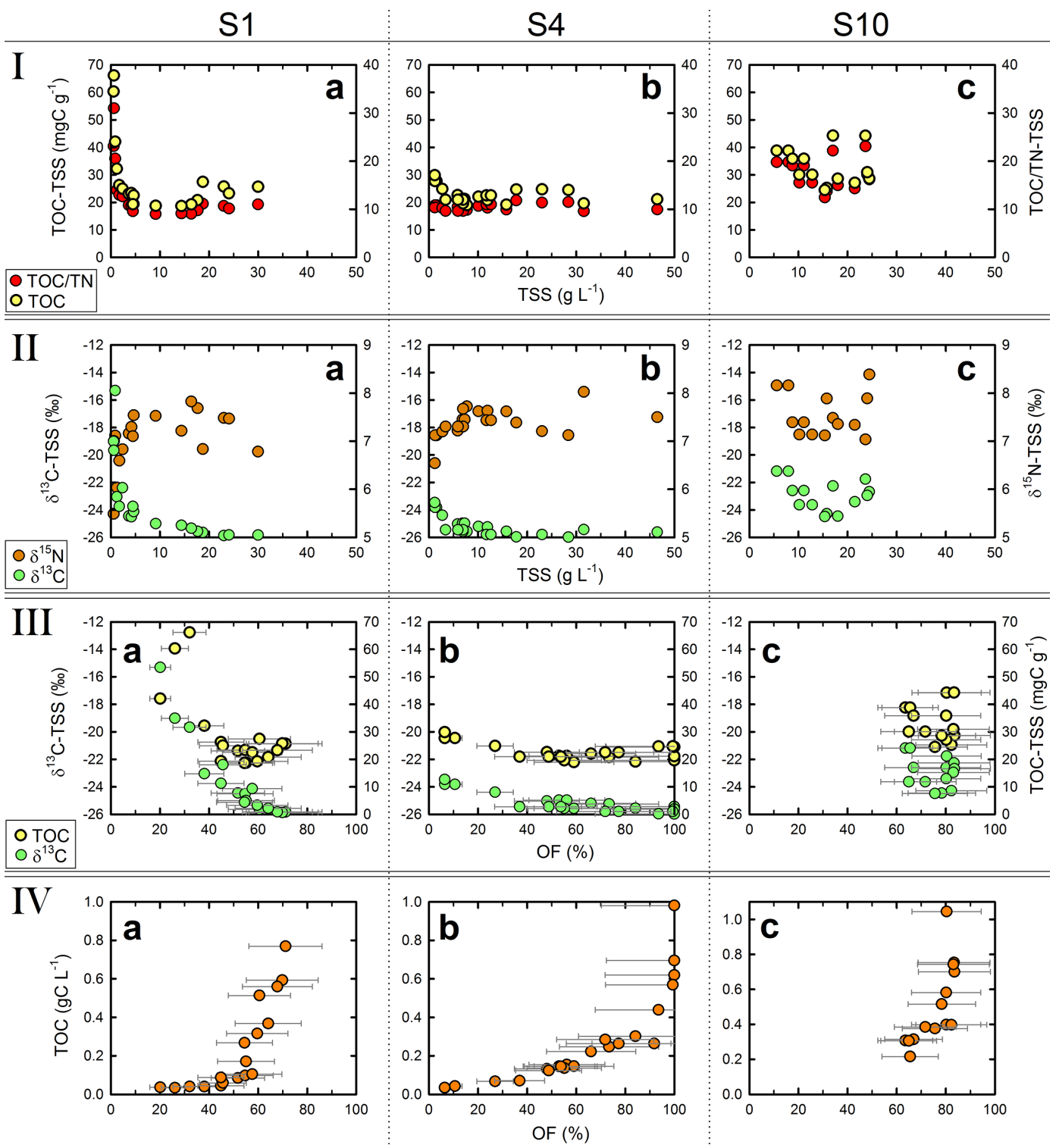

Figure 5. Relationships between total suspended sediment load (TSS), total organic carbon concentration in the TSS (TOC-TSS), total organic carbon : total nitrogen ratio in the TSS (TOC / TN-TSS), $\delta^{13} \mathrm{C}-\mathrm{TSS}, \delta^{15} \mathrm{~N}$-TSS, total organic carbon load (TOC) and overland flow contribution estimates (OF): (a) at upstream station S1 (Houay Pano stream), (b) at intermediate station S4, and (c) at downstream station S10, during the 23 May 2012 flood. In (III) and (IV), circles represent the median values of the variability range (horizontal bars) of estimated OF contribution.

\subsection{Particulate organic matter delivery during the 23 May 2012 flood}

\subsubsection{Sources of suspended organic matter in the catchment}

Variations in the composition of particulate organic matter reflect changes in the source supplying suspended sediment in the catchment during the flood. For S1 and S4, this evolution follows hyperbolic trends with suspended sediment loads for TOC, $\delta^{13} \mathrm{C}$ and $\delta^{15} \mathrm{~N}$ and tends to reach the mean composition of catchment surface soils during the main transport phase (Fig. 5I/IIa-b). As reported by Bellanger et al. (2004) in the Venezuelan Andes, this behaviour indicates that sheet erosion was likely the dominant process. The composition of suspended sediments in the study area is consistent with the supply of carbonate free soil-detached particles exported from catchment's soils.

However, Meybeck (1993) outlined that hyperbolic trends may indicate that a significant fraction of particulate organic matter exported from mountainous regions by rivers may be supplied by the direct erosion of sedimentary-metamorphic 


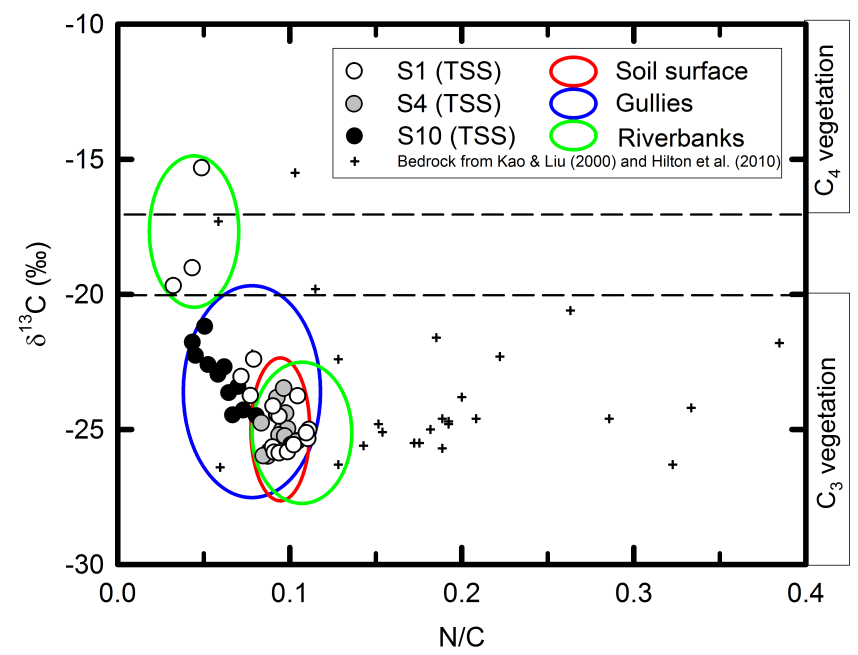

Figure 6. Plot of $\delta^{13} \mathrm{C}$ vs. TN / TOC for total suspended sediment loads (TSS) collected at S1 (open circles), S4 (grey circles) and S10 (closed circles) during the 23 May 2012 flood and for the potential sources of sediment (Soil surface: red area; Gullies: blue area; Riverbanks: green areas) determined in the catchment. Bedrock data (plus signs) are taken from the literature (Kao and Liu, 2000; Hilton et al., 2010).

bedrock (the so-called "fossil carbon" pool) and pointed out that neglecting this source induces a bias in carbon budgets. Fossil carbon may supply $90-100 \%$ of total particulate organic matter exported in rivers with average annual suspended loads exceeding $5 \mathrm{~g} \mathrm{~L}^{-1}$ (Meybeck, 2006). In the Andes, Clark et al. (2013) identified fossil POC contributions associated with TSS concentrations exceeding $1 \mathrm{~g} \mathrm{~L}^{-1}$. In a Taiwanese river, Hilton et al. (2011) reported suspended sediment concentrations up to ca. $30 \mathrm{~g} \mathrm{~L}^{-1}$ with fossil POC concentrations up to ca. $0.1 \mathrm{gL}^{-1}$. Our results do not support the hypothesis of a significant supply of rock-derived fossil carbon, which is often associated with important sediment exports originating from gully systems (Duvert et al., 2010), landslides and mass movements. These erosion processes were not observed in the Houay Pano catchment during the study period. The few bedrock outcrops are not directly connected to the stream. Moreover, the highest $\delta^{15} \mathrm{~N}$ values measured in suspended sediment samples reflect the occurrence of soil derived organic matter rather than fossil organic matter (e.g. Huon et al., 2006). The latter should theoretically provide lower $\delta^{15} \mathrm{~N}$ values than those found in soils. Preservation of organic matter in sedimentary and low-grade metamorphic rocks takes place at "high temperature" (limited ${ }^{15} \mathrm{~N} /{ }^{14} \mathrm{~N}$ fractionation with respect to vegetation) whereas incorporation and stabilization of organic matter in soils should occur at "low surface temperature" (enhanced ${ }^{15} \mathrm{~N} /{ }^{14} \mathrm{~N}$ fractionation). Fossil particulate organic carbon contributions have been identified using ${ }^{14} \mathrm{C}$ natural abundance and C-N stable isotope measurements in various studies (e.g. Kao and Liu, 1997; Raymond and Bauer, 2001;
Copard et al., 2007; Graz et al., 2012; Smith et al., 2013). This approach could be applied to Houay Pano samples in the future to further characterize the particulate organic matter. However, the activities in ${ }^{137} \mathrm{Cs}$ that was supplied in the 1960s by atmospheric thermonuclear bomb fallout (Ritchie and McHenry, 1990) measured in suspended sediments collected in Houay Pano and Houay Xon Rivers remain in the same range as surface soil activities (above $1 \mathrm{~Bq} \mathrm{~kg}^{-1}$; Table 1; Gourdin et al., 2014). This result confirms that they may not originate from Paleozoic bedrock.

\subsubsection{Dynamics of suspended organic matter}

The ${ }^{13} \mathrm{C}$-enriched compositions of material collected at $\mathrm{S} 1$ (Fig. 5IIa) first reflect the supply of organic matter derived from $\mathrm{C}_{4}$ photosynthetic pathway plants. Then, with increasing water discharge, suspended sediments progressively incorporate ${ }^{13} \mathrm{C}$-depleted organic matter originating from soils covered by $\mathrm{C}_{3}$ photosynthetic pathway plants that dominate in the drainage area. Decreasing TOC / TN (increasing $\mathrm{TN} / \mathrm{TOC}$ ) and increasing $\delta^{15} \mathrm{~N}$ trends during the flood are best explained by the re-suspension of weakly mineralized (low $\delta^{15} \mathrm{~N}$ ) $\mathrm{C}_{4}$-plant debris (high TOC / TN), followed by their mixing with soil organic matter exported from cultivated fields and supplied by overland flow to the main stream (low TOC / TN, high $\delta^{15} \mathrm{~N}$ ). A plot of $\delta^{13} \mathrm{C}$ vs. TN / TOC shows that the composition of suspended sediment matches that of the main pools of particulate organic matter in the catchment, i.e. surface soils and subsurface soils (gullies and river banks, Fig. 6). Mixing between the two end-members is pictured by linear relationships between both parameters for $\mathrm{S} 1$ and S10.

Bedrock source compositions available from the literature for tropical catchments (i.e. Kao and Liu, 2000, Hilton et al., 2010) fall outside the observed mixing trends. In addition, the occurrence of light density charcoal fragments produced by slash-and-burn cultivation might have slightly increased TOC / TN with respect to soil bulk organic matter (Soto et al., 1995; Rumpel et al., 2006). Overland flow supply of particulate organic matter exported from soils that are currently or were previously cultivated with upland rice is largely dominant at $\mathrm{S} 4$ compared to S1 (Fig. 5I/IIa-b). Fields cropped with $\mathrm{C}_{4}$-plants only cover small areas in the catchment and their imprint on soil organic matter composition is therefore limited (Huon et al., 2013; de Rouw et al., 2015). The $\delta^{13} \mathrm{C}$ recorded during and after the water discharge peak were similar $(-25.7 \%$; Fig. 5IIa-b) to those of surface soils, reflecting the dominance of surface vs. subsurface sources in the Houay Pano catchment. At S8, located close to S4 (Fig. 1), $\delta^{15} \mathrm{~N}$ increased noticeably from 6.5 to $8.3 \%$ during the storm, indicating that ${ }^{15} \mathrm{~N}$-depleted organic matter (i.e. vegetation debris) was first exported and that erosion progressively affected deeper ${ }^{15} \mathrm{~N}$-enriched layers of the topsoil (Table 1). In contrast to the two other stations, the maximum TOC / TN (23) recorded downstream at S10 occurred during 
Table 3. Total suspended sediment yield (SSY), total particulate organic carbon yield $\left(\mathrm{C}_{\mathrm{SSY}}\right)$, specific total suspended sediment yield $\left(S_{Y}\right)$ and specific total organic carbon yield $\left(\mathrm{C}_{\mathrm{Y}}\right)$ for the 23 May 2012 flood.

\begin{tabular}{lrrrr}
\hline Station & $\begin{array}{r}\text { SSY } \\
(\mathrm{Mg})\end{array}$ & $\begin{array}{r}\mathrm{C}_{\mathrm{SSY}} \\
(\mathrm{kg})\end{array}$ & $\begin{array}{r}S_{\mathrm{Y}^{*}} \\
\left(\mathrm{~kg} \mathrm{ha}^{-1}\right)\end{array}$ & $\begin{array}{r}\mathrm{C}_{\mathrm{Y}}^{* *} \\
\left(\mathrm{kgCha}^{-1}\right)\end{array}$ \\
\hline S1 & 2.3 & 58 & 115 & 2.9 \\
S4 & 26 & 496 & 433 & 8.3 \\
S10 & 130 & 4346 & 112 & 3.7 \\
\hline
\end{tabular}

$* S_{\mathrm{y}}=10 \times \mathrm{SSY} /$ drainage area in Table 2 ;

** $\mathrm{C}_{\mathrm{Y}}=10^{-2} \times \mathrm{C}_{\mathrm{SSY}} /$ drainage area in Table 2 .

the water discharge peak (Figs. 3IIIf and 5Ic). Fresh organic matter characterized by high ratios is exported with a time lag due to the remote location of its source (Gurnell, 2007). Suspended organic matter transported at the beginning of the flood (range: from -23 to $-21 \%$; Table A1, Fig. 5IIIc) is enriched in ${ }^{13} \mathrm{C}$ and ${ }^{15} \mathrm{~N}$ compared to the mean surface soil and matches subsurface soil signatures (stream banks and gullies, Table 1). This observation supports previous findings showing the dominance of riverbank erosion characterized by the depletion in fallout radionuclides measured for sediments collected at this station (Gourdin et al., 2014). Positive correlative trends between soil TOC and ${ }^{137} \mathrm{Cs}$ inventories suggest that a similar process, i.e. erosion and erosioninduced carbon depletion, controlled their concomitant decrease since the onset of cultivation in the 1960s (Huon et al., 2013). Smith and Blake (2014) reported similar correlations for riverine sediments in some of their study sites. We could not derive any similar relationship during the 23 May 2012 flood (data not shown).

Contribution of overland flow to stream water discharge derived from hydrograph separation can be linked to the source of suspended organic matter (Fig. 5III) as well as to the extent of particulate organic matter transfer (Fig. 5IV). In terms of water - sediment dynamics, high OF contributions (above ca. $50 \%$ ) supply large quantities of soil organic matter, characterized by lower TOC contents and enriched isotopic compositions compared to fresh vegetation debris, to the river. In contrast, low OF contributions may indicate the dominance of riverbank erosion and remobilization of sediment deposited on the riverbed during previous floods. Based on hydrograph separation, it is then possible to draw sediment and particulate organic carbon budgets at the catchment's scale in areas where surface soil erosion dominates.

\subsubsection{Suspended sediment and particulate organic carbon deliveries}

Total suspended sediment exports are summarized in Table 3 for S1, S4 and S10 sub-catchments.

Compared to the annual sediment yield measured in 20022003 at S4 (2090 $\left.\mathrm{kg} \mathrm{ha}^{-1} \mathrm{yr}^{-1}\right)$ and S10 $\left(540 \mathrm{~kg} \mathrm{ha}^{-1} \mathrm{yr}^{-1}\right)$ reported by Chaplot and Poesen (2012), the 23 May 2012 flood represented ca. $21 \%$ of the total annual exports recorded at both stations. These deliveries are high for a single rainfall event of moderate intensity. However, fallout radionuclide measurements (Gourdin et al., 2014) indicate that this flood was the first important erosive event of the 2012 rainy season and that it mainly exported remobilized river channel sediment (ca. $80 \%)$. The TSS yield $\left(S_{Y}\right)$ of ca. $433 \mathrm{~kg} \mathrm{ha}^{-1}\left(8.3 \mathrm{~kg} \mathrm{Cha}^{-1}\right)$ at $\mathrm{S} 4$ is greater than at $\mathrm{S} 1$ and S10 (Table 3) and remains consistent with higher specific runoff and runoff coefficient values recorded at this station (Table 2). Overall, we did not observe any decrease in specific carbon delivery when the drainage area of catchments increased. This counter-intuitive result is likely explained by the occurrence of a swamp along the main stream between S1 and S4. In the upper part of the catchment, it acts like a filter for sediments conveyed during low to medium magnitude floods (Fig. 1). In this swamp, Napier grass reduces stream flow velocity and enhances particle deposition. About $33 \mathrm{Mg}$ of soil-derived organic carbon was estimated to have accumulated in this area since the early 1960s (Huon et al., 2013). This swamp therefore played a key role by reducing downstream export of suspended sediment during the 23 May 2012 flood. It also explains why the high $\delta^{13} \mathrm{C}$ values of TSS loads observed during the rising water stage upstream of the swamp (at S1) are not found in sediments collected at S4. Soil-derived organic matter supplied by overland flow supplied the major part of the TSS during the rising stage, downstream of the swamp. A comparable role of sediment filter can be attributed to the wetlands located at the outlet of the village. However, in contrast the latter mainly supplied streambank material to the river. As they were covered by Napier grass, this channel bank material was characterized by higher $\delta^{13} \mathrm{C}$ values as measured at $\mathrm{S} 10$. The shift in the POC signature thereby confirms the results obtained with radionuclide activity measurements carried out on the same samples (Gourdin et al., 2014). 


\section{Concluding remarks}

The composition of suspended organic matter and stream water was measured during the first erosive flood of the 2012 rainy season in a cultivated catchment of northern Laos. These measurements provided an efficient way to quantify the contribution of particulate organic matter sources along a network of nested gauging stations.

Quantification of the overland flow contribution (rather than rainfall) with hydrological tracers $\left(\delta^{18} \mathrm{O}\right.$ and electrical conductivity) strengthened the procedure used to identify the sources of particulate organic matter in the catchment.

In the upper part of the drainage basin (Houay Pano subcatchment), the composition of suspended organic matter shows that sediment mainly originated from in-channel and nearby sources during the rising stage and from cultivated topsoil during peak flow and the flood recessing stage.
Downstream, the composition of suspended organic matter in the Houay Xon River reflected the dominant supply of subsurface sources (riverbanks and gullies) and a subsequent dilution of soil-derived organic matter delivery by channelbank mixing and mobilization processes.

Wetlands and swamps played a key role by trapping sediment in the upstream and steeper part of the catchment and by remobilizing riverbank deposits further downstream.

Overall, the specific particulate organic matter delivery estimated at the catchment outlet was rather high for a flood of moderate magnitude, and this result was attributed to its occurrence at the onset of the rainy season, after field clearing by slash-and-burn operations. 


\section{Appendix A}

Table A1. Summary of data for stations S1, S4 and S10 during the 23 May 2012 flood.

\begin{tabular}{|c|c|c|c|c|c|c|c|c|c|c|}
\hline Label & $\begin{array}{c}\text { Time }^{\mathrm{a}} \\
\text { (hh:mm) }\end{array}$ & $\begin{array}{c}\mathrm{TSS}^{\mathrm{a}} \\
\left(\mathrm{gL}^{-1}\right)\end{array}$ & $\begin{array}{c}Q^{\mathrm{a}} \\
\left(\mathrm{Ls}^{-1}\right)\end{array}$ & $\begin{array}{c}\mathrm{EC}^{\mathrm{a}} \\
\left(\mu \mathrm{Scm}^{-1}\right)\end{array}$ & $\begin{array}{c}\delta^{18} \mathrm{O}^{\mathrm{a}}(\% \circ \mathrm{vs} . \\
\mathrm{V}-\mathrm{SMOW})\end{array}$ & $\begin{array}{c}\mathrm{TOC}^{\mathrm{a}} \\
\left(\mathrm{mgCg}^{-1}\right)\end{array}$ & $\begin{array}{c}\mathrm{TN}^{\mathrm{a}} \\
\left(\mathrm{mgNg}^{-1}\right)\end{array}$ & $\mathrm{TOC} / \mathrm{TN}^{\mathrm{a}}$ & $\begin{array}{l}\delta^{13} \mathrm{C}^{\mathrm{a}}(\% o \\
\text { vs. PDB) }\end{array}$ & $\begin{array}{c}\delta^{15} \mathrm{~N}^{\mathrm{a}}(\% \circ \\
\text { vs. AIR) }\end{array}$ \\
\hline \multicolumn{11}{|l|}{ Station S1 } \\
\hline LS0101 & $12: 08$ & 0.86 & 5 & 335 & -7.2 & 42.0 & 2.0 & 20.5 & -15.3 & 7.1 \\
\hline LS0102 & 12:09 & 0.56 & 7 & 317 & -7.1 & 60.3 & 2.6 & 23.1 & -19.0 & 5.5 \\
\hline LS0103 & 12:09 & 0.53 & 10 & 317 & -7.0 & - & - & - & - & - \\
\hline LS0104 & $12: 10$ & 0.61 & 13 & 299 & -6.8 & 66.2 & 2.1 & 31.0 & -19.7 & 7.0 \\
\hline LS0105 & $12: 10$ & - & 16 & 299 & - & - & - & - & - & - \\
\hline LS0106 & $12: 11$ & 1.23 & 21 & 282 & -6.9 & 32.2 & 2.3 & 14.0 & -23.0 & 6.0 \\
\hline LS0107 & $12: 13$ & 1.70 & 27 & 262 & -6.6 & 26.2 & 2.0 & 13.0 & -23.7 & 6.6 \\
\hline LS0108 & $12: 14$ & 2.37 & 34 & 259 & -6.2 & 25.0 & 2.0 & 12.7 & -22.4 & 6.8 \\
\hline LS0109 & $12: 19$ & 3.65 & 40 & 241 & -6.0 & 23.1 & 2.1 & 10.8 & -24.4 & 7.2 \\
\hline LS0110 & $12: 20$ & 4.17 & 55 & 233 & -6.1 & 23.4 & 2.2 & 10.7 & -24.5 & 7.3 \\
\hline LS0111 & $12: 21$ & 4.65 & 76 & 224 & -5.9 & 22.5 & 2.0 & 11.1 & -24.1 & 7.5 \\
\hline LS0112 & $12: 21$ & 18.74 & 90 & 215 & -5.8 & 27.4 & 2.0 & 11.1 & -25.6 & 6.8 \\
\hline LS0113 & $12: 30$ & 29.98 & 68 & 184 & -5.8 & 25.7 & 2.1 & 11.0 & -25.8 & 6.8 \\
\hline LS0114 & $12: 33$ & 23.02 & 51 & 188 & -5.5 & 25.8 & 2.2 & 10.7 & -25.9 & 7.5 \\
\hline LS0115 & $12: 37$ & 24.05 & 38 & 194 & -5.4 & 23.3 & 2.0 & 10.1 & -25.8 & 7.5 \\
\hline LS0116 & $12: 43$ & 17.67 & 27 & 205 & -5.6 & 20.8 & 2.5 & 9.8 & -25.6 & 7.7 \\
\hline LS0117 & $12: 50$ & 16.38 & 18 & 218 & -5.7 & 19.3 & 2.3 & 9.0 & -25.3 & 7.8 \\
\hline LS0118 & $12: 57$ & 9.13 & 14 & 232 & -5.8 & 18.7 & 2.4 & 9.0 & -25.0 & 7.5 \\
\hline LS0119 & $12: 58$ & 14.37 & 13 & 233 & -6.1 & 18.6 & 2.3 & 9.1 & -25.1 & 7.2 \\
\hline LS0120 & $13: 15$ & 4.50 & 8 & 262 & -6.2 & 19.3 & 2.1 & 9.6 & -23.8 & 7.1 \\
\hline \multicolumn{11}{|l|}{ Station S4 } \\
\hline LS0403 & $11: 57$ & 1.53 & 15 & 297 & -6.9 & - & - & - & - & - \\
\hline LS0404 & $11: 58$ & 1.21 & 24 & 306 & -6.7 & - & - & - & - & - \\
\hline LS0403-4 & - & - & - & - & - & 27.7 & 2.6 & 10.8 & -23.8 & 7.1 \\
\hline LS0405 & $12: 00$ & 1.16 & 33 & 306 & -6.5 & 29.9 & 2.9 & 10.4 & -23.5 & 6.5 \\
\hline LS0406 & $12: 01$ & 2.71 & 42 & 262 & -6.1 & 24.8 & 2.4 & 10.2 & -24.4 & 7.2 \\
\hline LS0407 & $12: 04$ & 5.83 & 54 & 216 & -5.5 & 22.6 & 2.2 & 10.5 & -25.0 & 7.2 \\
\hline LS0408 & $12: 05$ & 6.83 & 76 & 205 & -5.2 & - & - & - & - & - \\
\hline LS0409 & $12: 06$ & 7.25 & 114 & 198 & -5.3 & - & - & - & - & - \\
\hline LS0408-9b & - & - & - & - & - & 21.2 & 2.1 & 10.1 & -25.0 & 7.5 \\
\hline LS0410 & $12: 07$ & 10.07 & 144 & 177 & -4.7 & 22.1 & 2.1 & 10.7 & -25.2 & 7.6 \\
\hline LS0411 & $12: 07$ & 11.89 & 185 & 161 & -4.7 & 20.8 & 2.0 & 10.3 & -25.2 & 7.6 \\
\hline LS0412 & $12: 08$ & 15.75 & 280 & 138 & -4.5 & 19.2 & 1.9 & 9.9 & -25.6 & 7.6 \\
\hline LS0413 & $12: 09$ & 20.05 & 309 & 121 & -4.9 & - & - & - & - & - \\
\hline LS0414 & $12: 10$ & 31.56 & 358 & 99 & -5.1 & 19.6 & 2.1 & 9.6 & -25.4 & 8.0 \\
\hline LS0415 & $12: 11$ & 46.51 & 440 & 87 & -5.2 & 21.1 & 2.1 & 10.0 & -25.6 & 7.5 \\
\hline LS0416 & $12: 20$ & 28.40 & 335 & 103 & -5.4 & 24.5 & 2.1 & 11.5 & -26.0 & 7.1 \\
\hline LS0417 & $12: 23$ & 23.00 & 277 & 105 & -5.4 & 24.7 & 2.2 & 11.4 & -25.8 & 7.2 \\
\hline LS0418 & $12: 26$ & 17.76 & 228 & 117 & -5.6 & 24.7 & 2.1 & 11.8 & -26.0 & 7.4 \\
\hline LS0419 & $12: 34$ & 11.70 & 183 & 152 & -5.6 & - & - & - & - & - \\
\hline LS0420 & $13: 20$ & 12.62 & 145 & 164 & -5.6 & - & - & - & - & - \\
\hline LS0419-20 & - & - & - & - & - & 22.5 & 2.0 & 11.0 & -25.8 & 7.4 \\
\hline LS0421 & $13: 32$ & 7.71 & 112 & 192 & -5.8 & 19.0 & 1.9 & 9.8 & -25.6 & 7.7 \\
\hline LS0422 & $13: 46$ & 6.92 & 84 & 201 & -6.1 & 19.6 & 2.0 & 9.8 & -25.6 & 7.7 \\
\hline LS0423 & $14: 05$ & 6.93 & 59 & 203 & -6.0 & - & - & - & - & - \\
\hline LS0424 & $14: 43$ & 5.89 & 39 & 214 & -6.2 & - & - & - & - & - \\
\hline LS0425 & $15: 46$ & 3.37 & 23 & 230 & -6.2 & - & - & - & - & - \\
\hline LS0423-25 & - & - & - & - & - & 20.9 & 2.2 & 9.6 & -25.5 & 7.3 \\
\hline \multicolumn{11}{|l|}{ Station S10 } \\
\hline LS1002 & $12: 24$ & 7.94 & 204 & 227 & -5.5 & - & - & - & - & - \\
\hline LS1003 & $12: 28$ & 5.57 & 455 & 220 & -5.5 & - & - & - & - & - \\
\hline LS1002-3 ${ }^{b}$ & - & - & - & - & - & 39 & 2.0 & 19.8 & -21.2 & 8.2 \\
\hline LS1004 & $12: 31$ & 8.77 & 623 & 215 & -5.9 & - & - & - & - & - \\
\hline LS1005 & $13: 03$ & 11.10 & 943 & 167.5 & -5.6 & - & - & - & - & - \\
\hline LS1004-5 ${ }^{b}$ & - & - & - & - & - & 36 & 1.9 & 19.1 & -22.6 & 7.4 \\
\hline LS1006 & 13:06 & 23.63 & 990 & 167 & -5.7 & 44 & 1.9 & 23.1 & -21.8 & 7.0 \\
\hline LS1007 & $13: 27$ & 17.02 & 1535 & 156 & -5.4 & 44 & 2.0 & 22.2 & -22.3 & 7.5 \\
\hline LS1008 & $13: 33$ & 24.43 & 1350 & 155.5 & -5.7 & 29 & 1.8 & 16.2 & -22.7 & 8.4 \\
\hline LS1009 & $13: 39$ & 24.00 & 1187 & 157 & -5.6 & 31 & 1.8 & 17.2 & -23.0 & 7.9 \\
\hline LS1010 & $13: 46$ & 15.74 & 1038 & 160 & -5.6 & 25 & 1.8 & 13.7 & -24.3 & 7.9 \\
\hline LS1011 & $13: 55$ & 21.47 & 886 & 167.5 & -5.7 & 27 & 1.9 & 14.3 & -23.4 & 7.3 \\
\hline LS1012 & $14: 06$ & 18.01 & 735 & 174 & -5.6 & 29 & 1.9 & 15.0 & -24.5 & 7.4 \\
\hline LS1013 & $14: 20$ & 15.35 & 597 & 184 & -5.8 & 24 & 2.0 & 12.4 & -24.5 & 7.1 \\
\hline LS1014 & $14: 38$ & 12.80 & 485 & 198 & -5.7 & - & - & - & - & - \\
\hline LS1015 & $15: 14$ & 10.17 & 308 & 222 & -5.9 & - & - & - & - & - \\
\hline LS1014-15 & - & - & - & - & - & 30 & 1.9 & 15.5 & -23.6 & 7.1 \\
\hline
\end{tabular}


Acknowledgements. The authors would like to thank the Lao NAFRI (National Agriculture and Forestry Research Institute in Vientiane) and the MSEC project (Multi-Scale Environment Changes) for their support. They are also grateful to Keo Oudone Latsachack, Bounsamai Soulileuth and Chanthamousone Thammahacksa for their help in the field, to Véronique Vaury (iEES Paris) for organic matter composition measurements, and to Patricia Richard (iEES Thiverval-Grignon) for $\delta^{18} \mathrm{O}$ measurements of water samples. Elian Gourdin received a PhD fellowship from Paris-Sud University, Orsay, France. This work received financial support from the French CNRS EC2CO/BIOHEFECT program (Belcrue project). The authors are grateful for the constructive comments of two anonymous referees who helped improve a previous draft of the manuscript.

Edited by: S. Bouillon

\section{References}

Amundson, R., Austin, A. T., Schuur, E. A. G., Yoo, K., Matzek, V., Kendall, C., Uebersax, A., Brenner, D., and Baisden, W. T.: Global patterns of the isotopic composition of soil and plant nitrogen, Global Biogeochem. Cy., 17, 1031, doi:10.1029/2002GB001903, 2003.

Balesdent, J., Girardin, C., and Mariotti, A.: Site-related $\delta^{13} \mathrm{C}$ of tree leaves and soil organic matter in a temperate forest, Ecology, 74, 1713-1721, 1993.

Bellanger, B., Huon, S., Velasquez, F., Vallès, V., Girardin, C., and Mariotti, A.: Monitoring soil organic carbon erosion with $\delta^{13} \mathrm{C}$ and $\delta^{15} \mathrm{~N}$ on experimental field plots in the Venezuelan Andes, Catena, 58, 125-150, 2004.

Ben Slimane, A., Raclot, D., Evrard, O., Sanaa, M., Lefèvre, I., Ahmadi, M., Tounsi, M., Rumpel, C., Ben Mammou, A., and Le Bissonnais, Y.: Fingerprinting sediment sources in the outlet reservoir of a hilly cultivated catchment in Tunisia, J. Soils Sediments, 13, 801-815, 2013.

Bricquet, J.-P., Boonsaner, A., Bouahom, B., and Toan, T. D.: Statistical Analysis of Long Series Rainfall Data: A Regional Study in South-East Asia, in: from soil research to land and water management: harmonizing people and nature: proceedings of the IWMIADB project annual meeting and 7th MSEC assembly, edited by: Maglinao, A. R., Valentin, C., and Penning de Vries, F., Vientiane (LAO), Vientiane (LAO): IWMI-ADB Project Annual Meeting; MSEC Assembly, 7, 83-89, 2003.

Buttle, J. M.: Isotope hydrograph separations and rapid delivery of pre-event water from drainage basins, Prog. Phys. Geogr., 18, 16-41, 1994.

Chaplot, V. and Poesen, J.: Sediment, soil organic carbon and runoff delivery at various spatial scales, Catena, 88, 46-56, 2012.

Chaplot, V., Coadoulebrozec, E., Silvera, N., and Valentin, C.: Spatial and temporal assessment of linear erosion in catchments under sloping lands of northern Laos, Catena, 63, 167-184, 2005.

Chaplot, V., Podwojewski, P., Phachomphon, K., and Valentin, C.: Soil erosion impact on soil organic carbon spatial variability on steep tropical slopes, Soil Sci. Soc. Am. J., 73, 769-779, 2009.

Chow, V. T., Maidment, D. R., and Mays, L. W.: Applied Hydrology, McGraw Hill Book Co., 572 pp., 1988.
Clark, K. E., Hilton, R. G., West, A. J., Malhi, Y., Gröcke, D. R., Bryant, C. L., Ascough, P. L., Robles Caceres, A., and New, M.: New views on "old" carbon in the Amazon River: Insight from the source of organic carbon eroded from the Peruvian Andes, Geochemistry, Geophysics, Geosystems, 14, 1644-1659, 2013.

Copard, Y., Amiotte-Suchet, P., and Di-Giovanni, C.: Storage and release of fossil organic carbon related to weathering of sedimentary rocks, Earth Planet. Sci. Lett., 258, 345-357, 2007.

Coplen, T. B., Kendall, C., and Hopple, J.: Comparison of stable isotope reference samples, Nature, 302, 236-238, 1983.

Dansgaard, W.: Stable isotopes in precipitation, Tellus, 16, 436468, 1964.

Degens, E. T., Kempe, S., and Richey, J. E.: Summary: Biogeochemistry of major world rivers, in: Biogeochemistry of major world rivers, edited by: Degens, E. T., Kempe, S., and Richey, J. E., SCOPE Rep. 42, John Wiley and Sons, Chichester, 323-347, 1991.

de Rouw, A., Soulileuth, B., and Huon, S.: Stable carbon isotope ratios in soil and vegetation shift with cultivation, Agriculture, Ecosyst. Environ., 200, 161-168, 2015.

Descroix, L., González Barrios, J. L., Viramontes, D., Poulenard, J., Anaya, E., Esteves, M., and Estrada, J.: Gully and sheet erosion on subtropical mountain slopes: Their respective roles and the scale effect, Catena, 72, 325-339, 2008.

Dixon, R. K., Brown, S., Houghton, R. A., Solomon, A. M., Trexler, M. C., and Wisniewski, J.: Carbon pools and flux of global forest ecosystems, Science, 263, 185-191, 1994.

Downing, J. A., Cole, J. J., Middelburg, J. J., Striegl, R. G., Duarte, C. M., Kortelainen, P., Prairie, Y. T., and Laube, K. A.: Sediment organic carbon burial in agriculturally eutrophic impoundments over the last century, Global Biogeochem. Cy., 22, 1-10, 2008.

Dupin, B., de Rouw, A., Phantahvong, K. B., and Valentin, C.: Assessment of tillage erosion rates on steep slopes in northern Laos, Soil Till. Res., 103, 119-126, 2009.

Duvert, C., Gratiot, N., Evrard, O., Navratil, O., Némery, J., Prat, C., and Esteves, M.: Drivers of erosion and suspended sediment transport in three headwater catchments of the Mexican Central Highlands, Geomorphology, 123, 243-256, 2010.

Ellis, E. E., Keil, R. G., Ingalls, A. E., Richey, J. E., and Alin, S. R.: Seasonal variability in the sources of particulate organic matter of the Mekong River as discerned by elemental and lignin analyses, J. Geophys. Res., 117, G01038, doi:10.1029/2011JG001816, 2012.

Epstein, S. and Mayeda, T.: Variation of ${ }^{18} \mathrm{O}$ content of waters from natural sources, Geochim. Cosmochim. Ac., 4, 213-224, 1953.

Evrard, O., Némery, J., Gratiot, N., Duvert, C., Ayrault, S., Lefèvre, I., Poulenard, J., Prat, C., Bonté, P., and Esteves, M.: Sediment dynamics during the rainy season in tropical highland catchments of central Mexico using fallout radionuclides, Geomorphology, 124, 42-54, 2010.

Gateuille, D., Evrard, O., Lefèvre, I., Moreau-Guigon, E., Alliot, F., Chevreuil, M., and Mouchel, J.-M.: Mass balance and depollution times of Polycyclic Aromatic Hydrocarbons in rural nested catchments of an early industrialized region (Orgeval River, Seine River basin, France), Sci. Total Environ., 470/471, 608-617, 2014.

Girardin, C. and Mariotti, A.: Analyse isotopique du ${ }^{13} \mathrm{C}$ en abondance naturelle un système automatique avec robot préparateur, Cah. Orstom, sér. Pédol., 120, 371-380, 1991. 
Goldsmith, S. T., Carey, A. E., Lyons, W. B., Kao, S.-J., Lee, T.-Y., and Chen, J.: Extreme storm events, landscape denudation, and carbon sequestration: Typhoon Mindulle, Choshui River, Taiwan, Geology, 36, 483-486, 2008.

Gonfiantini, R.: Standards for stable isotope measurements in natural compounds, Nature, 271, 534-536, 1978.

Gourdin, E., Evrard, O., Huon, S., Lefèvre, I., Ribolzi, O., Reyss, J.-L., Sengtaheuanghoung, O., and Ayrault, S.: Suspended sediment dynamics in a Southeast Asian mountainous catchment: combining river monitoring and fallout radionuclide tracers, J. Hydrol., 519, 1811-1823, 2014.

Graz, Y., Di-Giovanni, C., Copard, Y., Mathys, N., Cras, A., and Marc, V.: Annual fossil organic carbon delivery due to mechanical and chemical weathering of marly badlands areas, Earth Surf. Process. Landforms, 37, 1263-1271, 2012.

Gurnell, A. M.: Analogies between mineral sediment and vegetative particle dynamics in fluvial systems, Geomorphology, 89, 9-22, 2007.

Harris, D. M., McDonnell, J. J., and Rodhe, A.: Hydrograph separation using continuous open system isotope mixing, Water Resour. Res., 31, 157-171, 1995.

Hilton, R. G., Galy, A., Hovius, N., Horng, M.-J., and Chen, H.: The isotopic composition of particulate organic carbon in mountain rivers of Taiwan, Geochim. Cosmochim. Ac., 74, 3164-3181, 2010.

Hilton, R. G., Galy, A., Hovius, N., Horng, M.-J., and Chen, H.: Efficient transport of fossil organic carbon to the ocean by steep mountain rivers: An orogenic carbon sequestration mechanism, Geology, 39, 71-74, 2011.

Houghton, R. A.: Tropical deforestation and atmospheric carbon dioxide, Clim. Change, 19, 99-118, 1991.

Hsieh, J. C. C., Chadwick, O. A., Kelly, E. F., and Savin, S. M.: Oxygen isotopic composition of soil water: Quantifying evaporation and transpiration, Geoderma, 82, 269-293, 1998.

Huang, T.-H., Fu, Y.-H., Pan, P.-Y., and Chen, C.-T. A.: Fluvial carbon fluxes in tropical rivers, Curr. Opin. Environ. Sustain., 4, 162-169, 2012.

Huon, S., Bellanger, B., Bonté, P., Sogon, S., Podwojewski, P., Girardin, C., Valentin, C., De Rouw, A., Velasquez, F., Bricquet, J.P., and Mariotti, A.: Monitoring soil organic carbon erosion with isotopic tracers: two case studies on cultivated tropical catchments with steep slopes (Laos, Venezuela), in: Advances in Soil Science, Soil erosion and carbon dynamics, edited by: Roose, E., Lal, R., Barthès, B., Feller C., and Stewart, B. A., CRC Press, Boca Raton. Florida (USA), 301-328, 2006.

Huon, S., de Rouw, A., Bonté, P., Robain, H., Valentin, C., Lefèvre, I., Girardin, C., Le Troquer, Y., Podwojewski, P., and Sengtaheuanghoung O.: Long-term soil carbon loss and accumulation in a catchment following the conversion of forest to arable land in northern Laos, Agriculture, Ecosyst. Environ., 169, 43-57, 2013.

Kao, S. J. and Liu, K. K.: Fluxes of dissolved and nonfossil particulate organic carbon from an Oceania small river (Lanyang Hsi) in Taiwan, Biogeochemistry, 39, 255-269, 1997.

Kao, S. J. and Liu, K. K.: Stable carbon and nitrogen isotope systematics in a human- disturbed watershed (Lanyang-Hsi) in Taiwan and the estimation of biogenic particulate organic carbon and nitrogen fluxes, Global Biogeochem. Cy., 14, 189-198, 2000 .
Klaus, J. and McDonnell, J. J.: Hydrograph separation using stable isotopes: Review and evaluation, J. Hydrol., 505, 47-64, 2013.

Koiter, A. J., Owens, P. N., Petticrew, E. L., and Lobb, D. A.: The behavioural characteristics of sediment properties and their implications for sediment fingerprinting as an approach for identifying sediment sources in river basins, Earth-Sci. Rev., 125, 24-42, 2013.

Ladouche, B., Probst, A., Viville, D., Idir, S., Baqué, D., Loubet, M., Probst, J.-L., and Bariac, T.: Hydrograph separation using isotopic , chemical and hydrological approaches (Strengbach catchment, France), J. Hydrol., 242, 255-274, 2001.

Lal, R.: Soil erosion and the global carbon budget, Environ. Int., 29, 437-450, 2003.

Lenzi, M. A. and Marchi, L.: Suspended sediment load during floods in a small stream of the Dolomites (Northeastern Italy), Catena, 39, 267-282, 2000.

Ludwig, W., Probst, J., and Kempe, S.: Predicting the oceanic input of organic carbon by continental erosion, Global Biogeochem. Cy., 10, 23-41, 1996.

Mariotti, A., Lancelot, C., and Billen, G.: Natural isotopic composition of nitrogen as a tracer of origin for suspended organic matter in the Scheldt estuary, Geochim. Cosmochim. Ac., 48, 549-555, 1983.

Masiello, C. A. and Druffel, E. R. M.: Carbon isotope geochemistry of the Santa Clara River, Global Biogeochem. Cy., 15, 407-416, 2001.

McDonnell, J. J., Bonell, M., Stewart, M. K., and Pearce, A. J.: Deuterium variations in storm rainfall: implications for stream hydrograph separation, Water Resour. Res., 26, 455-458, 1990.

Meybeck, M.: Riverine transport of atmospheric carbon: sources, global typology and budget, Water. Air. Soil Pollut., 70, 443463, 1993.

Meybeck, M.: Origins and behaviors of carbon species in world rivers, in: Soil erosion and Carbon Dynamics, edited by: Roose, E., Lal, R.; Barthès, B., Feller C., and Stewart, B. A., CRC Press, Boca Raton, Florida (USA), 209-238, 2006.

Milliman, J. D. and Syvitski, J. P. M.: Geomorphic / tectonic control of sediment discharge to the ocean?: the importance of small mountainous rivers, J. Geol., 100, 525-544, 1992.

Patin, J., Mouche, E., Ribolzi, O., Chaplot, V., Sengtahevanghoung, O., Latsachak, K. O., Soulileuth, B., and Valentin, C.: Analysis of runoff production at the plot scale during a long-term survey of a small agricultural catchment in Lao PDR, J. Hydrol., 426/427, 79-92, 2012.

Quinton, J. N., Govers, G., Van Oost, K., and Bardgett, R. D.: The impact of agricultural soil erosion on biogeochemical cycling, Nat. Geosci., 3, 311-314, 2010.

Raymond, P. A. and Bauer, J. E.: Riverine export of aged terrestrial organic matter to the North Atlantic Ocean, Nature, 409, 497500, 2001.

Ribolzi, O., Andrieux, P., Valles, V., Bouzigues, R., Bariac, T., and Voltz, M.: Contribution of groundwater and overland flows to storm flow generation in a cultivated Mediterranean catchment, Quantification by natural chemical tracing, J. Hydrol., 233, 241257, 2000.

Ribolzi, O., Cuny, J., Sengsoulichanh, P., Pierret, A., Thiébaux, J. P., Huon, S., Bourdon, E., Robain, E., and Sengtaheuanghoung O.: Assessment of water quality along a tributary of the Mekong 
River in a mountainous, mixed land-use environment of the Lao P.D.R., Lao J. Agricult. Forest., 17, 91-111, 2008.

Ribolzi, O., Cuny, J., Sengsoulichanh, P., Mousquès, C., Soulileuth, B., Pierret, A., Huon, S., and Sengtaheuanghoung O.: Land use and water quality along a Mekong tributary in northern Lao P.D.R., Environ. Manage., 47, 291-302, 2010.

Ribolzi, O., Patin, J., Bresson, L. M., Latsachack, K. O., Mouche, E., Sengtaheuanghoung, O., Silvera, N., Thiébaux, J. P., and Valentin, C.: Impact of slope gradient on soil surface features and infiltration on steep slopes in northern Laos, Geomorphology, 127, 53-63, 2011.

Ritchie, J. C. and McHenry, J. R.: Application of Radioactive Fallout Cesium-137 for Measuring Soil Erosion and Sediment Accumulation Rates and Patterns?: A Review, J. Environ. Qual., 19, 215-233, 1990.

Ritchie, J. C. and McCarty, G. W.: ${ }^{137}$ Cesium and soil carbon in a small agricultural watershed, Soil Till. Res., 69, 45-51, 2003.

Rumpel, C., Chaplot, V., Planchon, O., Bernadou, J., Valentin, C., and Mariotti, A.: Preferential erosion of black carbon on steep slopes with slash and burn agriculture, Catena, 65, 30-40, 2006.

Sarmiento, J. L. and Gruber, N.: Sinks for anthropogenic carbon, Physics Today, 55, 30-36, 2002.

Schindler Wildhaber, Y., Liechti, R., and Alewell, C.: Organic matter dynamics and stable isotope signature as tracers of the sources of suspended sediment, Biogeosciences, 9, 1985-1996, doi:10.5194/bg-9-1985-2012, 2012.

Sklash, M. G. and Farvolden, R. N.: The role of groundwater in storm runoff, J. Hydrol., 43, 45-65, 1979.

Smith, H. G. and Blake, W. H.: Sediment fingerprinting in agricultural catchments: A critical re-examination of source discrimination and data corrections, Geomorphology, 204, 177-191, 2014.

Smith, J. C., Galy, A., Hovius, N., Tye, A. M., Turowski, J. M., and Schleppi, P.: Runoff-driven export of particulate organic carbon from soil in temperate forested uplands, Earth Planet. Sci. Lett., $365,198-208,2013$.
Soto, B., Basanta, R., Perez, R., and Diaz-Fierros, F.: An experimental study of the influence of traditional slash-and-burn practices on soil erosion, Catena, 24, 13-23, 1995.

Syvitski, J. P. M., Vörösmarty, C. J., Kettner, A. J., and Green, P. Impact of humans on the flux of terrestrial sediment to the global coastal ocean, Science, 308, 376-80, 2005.

Tanik, A., Beler Baykal, B., and Gonenc, I. E.: The impact of agricultural pollutants in six drinking water reservoirs, Water Sci. Technol., 40, 11-17, 1999.

Thothong, W., Huon, S., Janeau, J.-L., Boonsaner, A., de Rouw, A., Planchon, O., Bardoux, G., and Parkpian, P.: Impact of land use change and rainfall on sediment and carbon accumulation in a water reservoir of North Thailand, Agriculture, Ecosyst. Environ., 140, 521-533, 2011.

UNESCO (United Nations Educational Scientific and Cultural Organization): FAO/UNESCO Soil map of the world, $1: 5000000$ Vol.1. Paris: UNESCO, 1974.

Valentin, C., Agus, F., Alamban, R., Boosaner, A., Bricquet, J. P., Chaplot, V., de Guzman, T., de Rouw, A., Janeau, J. L., Orange, D., Phachomphonh, K., Podwojewski, P., Ribolzi, O., Silvera, N., Subagyono, K., Thiébaux, J. P., and Vadari, T.: Runoff and sediment losses from 27 upland catchments in Southeast Asia: Impact of rapid land use changes and conservation practices, Agriculture, Ecosyst. Environ., 128, 225-238, 2008.

Williams, G. P.: Sediment concentration versus water discharge during single hydrologic events in rivers, J. Hydrol., 111, 89-106, 1989.

Zech, W., Senesi, N., Guggenberger, G., Kaiser, K., Lehmann, J., Miano, T.M., Miltner, A., and Schroth, G.: Factors controlling humification and mineralization of soil organic matter in the tropics, Geoderma, 79, 117-161, 1997. 